\title{
Kürt Üniversite Öğrencilerinin Kimlik Yönetim Stratejileri ve Dış-Grup Tarafgirliğinin Kimlikle İlgili Eylem ve Hedeflerle İlişkileri: Açık ve Örtük Ölçümlerle Bir İnceleme
}

\author{
Kenan Alparslan ${ }^{1}$ \\ Muş Alparslan Üniversitesi
}

\author{
M. Ersin Kuşdil ${ }^{2}$ \\ Bursa Uludağ Üniversitesi
}

\begin{abstract}
Özet
$\mathrm{Bu}$ araştırmada, Kürt gençlerinin kimlik yönetim stratejileri, etnik kimlikle özdeşleşme düzeyleri, sosyal baskınlık yönelimleri ve sistemi meşrulaştırma eğilimlerinin yanı sıra, açık ve örtük biçimleri ölçülen dış-grup tarafgirlikleri kullanılarak etnik kimlikleriyle ilgili eylem ve hedeflerinin başlıca yordayıcılarının belirlenmesi amaçlanmıştır. Ayrıca, bahsedilen değişkenlerin etnik kimlikle ilgili eylem ve hedef yönelimleriyle ilişkileri kıyaslamalı olarak incelenmiştir. Araştırmaya 125 Kürt erkek üniversite öğrencisi katılmıştır. Analiz sonuçları kimliği destekleyici eylem ve hedeflerin rekabet stratejileriyle olumlu, hareketlilik ve kategorizasyon stratejileriyle ise olumsuz ilişkilere sahip olduğunu ortaya koymuştur. Yol analizleri genel olarak etnik kimlikle özdeşleşmenin rekabet stratejilerini olumlu, kategorizasyon stratejilerini ve dış-grup tarafgirliğini olumsuz yönde yordadığını göstermiştir. Sistemi meşrulaştırmanın hareketlilik ve kategorizasyon stratejilerinin yanı sıra, dış-grup tarafgirliğiyle de olumlu yönde ilişkili olduğu saptanmıştır. Sosyal baskınlık yönelimi ise sadece hareketlilik stratejilerini olumlu yönde yordamaktadır. Kimlikle ilgili eylem ve hedeflerin en güçlü yordayıcıları ise, sırasıyla, etnik özdeşleşme ile açık ve örtük dış-grup tarafgirlikleridir. Bu bulgular göz önüne alındığında, Sosyal Kimlik Kuramı ve Sistemi Meşrulaştırma Kuramı’nın ana değişkenlerinin Sosyal Baskınlık Kuramı'na göre, çeşitli strateji tercihlerini ve etnik kimlikle ilgili eylem ve hedefleri belirlemede daha başarılı olduğu söylenebilir. Araştırmada ele alınan kuramsal değişkenlerin her birinin farklı stratejileri açıklamada öne çıkıyor olması, bu değişkenlerin ilgili çalışmalarda birlikte ele alınmasının önemine işaret etmektedir.
\end{abstract}

Anahtar kelimeler: Etnik özdeşleşme, dış-grup tarafgirliği, kimlik yönetim stratejisi, örtük çağrışım testi, sistemi meşrulaştırma, sosyal baskınlık yönelimi

\begin{abstract}
This study aims to identify the main predictors of Kurdish youth's actions and goals related to their ethnic identities by using identity management strategies, ethnic identification, social dominance orientation, and system justification, as well as explicit and implicit outgroup favoritism. Also, the relationships of these variables with the action and goal orientations regarding ethnic identity were examined comparatively. The sample consisted of 125 Kurdish male university students. Results showed that identity-related actions and goals positively related to competition strategies and negatively related to mobility and categorization strategies. Path analyses revealed that ethnic identification predicted competition strategies positively, whereas it predicted categorization strategies and outgroup favoritism negatively. System justification predicted mobility and categorization strategies and outgroup favoritism positively. Social dominance orientation could only predict mobility strategies positively. The most powerful predictors of actions and goals related to ethnic identity were the variables of ethnic identification and explicit and implicit outgroup favoritism, respectively. Although the main variables of Social Identity and System Justification theories are more efficient in predicting various strategy preferences and identity-related actions and goals, compared to Social Dominance Theory, findings point out the importance of using these variables together when studying the identity management strategies.
\end{abstract}

Keywords: Ethnic identification, outgroup favoritism, identity management strategies, implicit association test, system justification, social dominance orientation

Yazışma Adresi: ${ }^{1}$ Arş. Gör. Kenan Alparslan, Muş Alparslan Üniversitesi, Fen-Edebiyat Fakültesi, Psikoloji Bölümü, Muş Alparslan Üniversitesi Külliyesi 49250 Güzeltepe / Muş, k.alparslan@alparslan.edu.tr, ORC-ID: 0000-0001-6701-355X

${ }^{2}$ Prof. Dr., Bursa Uludağ Üniversitesi, Fen-Edebiyat Fakültesi, Psikoloji Bölümü, mekusdil@uludag.edu.tr, ORC-ID: 0000-0002-3005-9009 Gönderim Tarihi: 15.11 .2018

Kabul Tarihi: 05.09 .2020 
Gruplar arası ilişkiler alanında yapılan çalışmalar çoğunlukla avantajlı (baskın, üst konumlu vb.) grupların dezavantajlı (azınlık, düşük konumlu vb.) gruplara karşı önyargılarını ve ayrımcılığını anlamaya yöneliktir (Wright, 2009). Bu çalışmalar avantajlı grupların onaylanmayan davranışlarının anlaşılması açısından değerli olsalar da dezavantajlı grup üyelerinin bu durumla nasıl başa çıktıklarının ve ne tür tepkiler sergilediklerinin uzun yıllar göz ardı edildiği de bir gerçektir. Psikoloji literatüründeki ilk çalışmalar, dezavantajlı grup üyelerinin kendilerine yönelik kalıpyargıları içselleştirdikleri ve kendi gruplarından nefret ettikleri üzerinde durmuştur (Clark ve Clark, 1947; Erikson, 1956). Sonraki y1llarda bu görüşlerin aksine, dezavantajlı grup üyelerinin maruz kaldıkları olumsuz süreçlerin pasif alıcıları olmadıkları, bu durumun üstesinden gelmek için çeşitli tepkiler sergiledikleri ileri sürülmüştür (Crocker ve Major, 1989; Tajfel ve Turner, 1979).

Bu kapsamda değerlendirilebilecek ilk teorik açılamalar Tajfel ve arkadaşları (1974; 1975; Tajfel ve Turner, 1979) tarafindan Sosyal Kimlik Kuramı (SKK) genel çerçevesinde yapılmıştır. Araştırmacılar, dezavantajlı grup üyelerinin olumlu bireysel kimliklere ve grup kimliklerine erişebilmek ve benlik saygılarını korumak ya da arttırmak amacıyla çeşitli stratejiler kullanabileceklerini ileri sürmüşlerdir. Bu stratejiler asimilasyondan rekabete dek uzanan bazı tepkileri kapsamaktadır.

SKK'ya eleştiriler getiren Sistemi Meşrulaştırma Kuramı (SMK; Jost ve Banaji, 1994) ise, bazı dezavantajlı grup üyelerinin kendi gruplarına yönelik olumsuz kalıpyargıları ve alt konumlarını içselleştirdiklerini iddia etmiştir. Bu kuram, insanların mevcut sosyal sistemleri meşru görme eğiliminde olduklarını ve bu sistemlerin devam etmesi için onları desteklediklerini ileri sürer. Özellikle de sistemden en çok zarar gören dezavantajlı grup üyelerinin o sistemi meşrulaştırarak dış-grup tarafgirliği sergilediklerini belirtir. SMK'ya benzer şekilde Sosyal Baskınlık Kuramı (SBK; Sidanius ve Pratto, 1999) da belirli bir toplumsal yapıda bulunan avantajlı grup üyelerinin iç-grup tarafgirliği, dezavantajlı grup üyelerinin ise diş-grup tarafgirliği sergileyerek mevcut hiyerarşik yapının sürmesine yardım ettiğini ileri sürer. Genel olarak bakıldığında, SKK, kimlik yönetim stratejisi kavramıyla, gruplar arası çatışmaya ve değişime yönelik çeşitli açıklamalar getirirken, SMK ve SBK dış-grup tarafgirliği olgusunu öne çıkartarak gruplar arası uyuşma ve düzenin sürmesine yönelik açıklamalar sunmaktadır.

Kimlik yönetim stratejilerini ele alan çalışmalar genellikle SKK çerçevesinde yapılmış ve stratejiler ile dış-grup tarafgirliği arasındaki ilişkiler nadiren ele alınmıştır (Mummendey, Klink, Mielke, Wenzel ve Blanz, 1999; Niens ve Cairns, 2002; Verkuyten ve Reijerse, 2008). Ayrıca, kimlik yönetim stratejileri üzerine çalışan araştırmacılar yordayıcı değişkenlerin sınırlı sayıda ve yetersiz olduğunu ifade etmişlerdir (Kessler ve Mummendey, 2002; Niens ve Cairns, 2003; Taylor ve McKirnan, 1984). Sosyal psikoloji literatürü incelendiğinde bu üç kuramı birlikte ele alarak kimlik yönetim stratejilerini veya dış-grup tarafgirliğini inceleyen herhangi bir çalışmaya rastlanmamıştır. Bu eksiklik göz önüne alındığında, olumsuz kimliğe yönelik tepkilerin anlaşılmasında üç büyük kuramın ana değişkenlerinin eş zamanlı kullanımı fayda sağlayacaktır. Bu çalışmanın yapılmasındaki temel neden de bu tür çalışmalara duyulan ihtiyaçtır.

$\mathrm{Bu}$ araştırmada, Kürt erkek üniversite öğrencilerinden oluşan bir örneklemde SKK, SBK ve SMK'nın ana değişkenleri olan, sırasıyla, etnik kimlikle özdeşleşme, sosyal baskınlık yönelimi (SBY) ve sistemi meşru algılamanın yanı sıra, kimlik yönetim stratejileri ve açık ve örtük biçimleri ölçülen dış-grup tarafgirliklerini kullanarak katılımcıların kimlikleriyle ilgili eylem ve hedeflerinin başlıca yordayıcılarının belirlenmesi amaçlanmıştır. $\mathrm{Bu}$ araştırmanın bulgularının Kürt erkek öğrencilerin sosyo-yapısal değişimi hedefleyen rekabet stratejilerine yönelmelerinin altında yatan temel faktörlerin neler olduğunun anlaşılmasına katkıda bulunacağına inanıyoruz.

\section{Kimlik Yönetim Stratejileri}

Tajfel ve Turner (1979) dezavantajlı grup üyelerinin, benlik saygılarını korumak ve olumlu bir sosyal kimlik edinmek için sergiledikleri davranışları 'olumsuz sosyal kimlik tepkileri' olarak tanımlamışlardır. Araştırmacılar, bu tepkileri bireysel hareketlilik, sosyal yaratıcilık ve sosyal rekabet şeklinde sınıflandırmışlardır (Tajfel ve Turner, 1979, ss. 43-44). Olumsuz sosyal kimlik tepkileri daha sonra 'kimlik yönetim stratejileri' olarak kavramsallaştırılmiştır (van Knippenberg, 1989; akt., Blanz, Mummendey, Mielke ve Klink, 1998). Blanz ve arkadaşları (1998), Doğu Almanlarla yaptıkları çalışmalarda dezavantajlı grup üyelerinin sergileyebilecekleri 12 ayrı kimlik yönetim stratejisi belirlemiş ve bu stratejileri beş grupta sınıflandırmışlardır. $\mathrm{Bu}$ siniflandırmaya göre, birinci grupta yer alan sosyal rekabet ve gerçekçi rekabet iç-grup ve diş-grup arasındaki statü ilişkilerinin değişimini amaçlayan kolektif ve davranışsal stratejilerdir. Bu iki strateji, dezavantajlı grup üyelerinin bireysel konumlarını iyileştirmek yerine, bir bütün olarak iç-gruplarını olumlu değerlendirmek ya da iç-grubun faydasına olan kaynakları eşit paylaşmak için hep birlikte mücadele etmelerine dayalıdır (Blanz ve ark., 1998; Ellemers, Wilke ve van Knippenberg, 1993). Rekabet stratejileri barışçıl girişimlerden şiddetli çatışmalara kadar çeşitli biçimlerde ortaya çıkabilir.

İkinci grubu oluşturan bireysel hareketlilik ve asimilasyon stratejileri iç-grup üyeliğinin değişimini amaçlayan bireysel ve davranışsal stratejilerdir. Bu stratejiler, olumsuz kimliğe yol açan dezavantajlı grup üyeliğinden ayrılıp 
daha yüksek statülü bir gruba geçmeye çabalama olarak da tanımlanır (Blanz ve ark., 1998). Söz konusu stratejilerin en önemli özelliği grubun konumunda bir değişikliğe yol açmayıp sadece o kişinin bireysel konumunda bir değişikliğin gerçekleşmesini sağlayabilmeleridir.

Üçüncü grup olan bireyselleşme, üst yeniden $k a$ tegorizasyon ve alt yeniden kategorizasyon stratejileri bilişsel stratejilerdir ve sosyal kategorizasyonun değişimini hedeflemektedirler. Bunlardan bireyselleşme stratejisi, isminden de anlaşılacağ ${ }_{1}$ gibi, kişisel bir stratejidir ve kişinin kendisini bir grup üyesi olarak görmesinden çok, bir birey olarak görmesini içerir. Kolektif stratejilerden olan üst yeniden kategorizasyon dezavantajlı grup üyesinin kendisini ortak bir iç-grup kimliği altında siniflandirması iken, alt yeniden kategorizasyon grup üyesinin kendisini iç-grubunun alt kimlikleriyle sınıflandırmasıdır (Blanz ve ark., 1998). Farklı dinsel inançlara sahip bireylerin kendilerini dindar olarak tanımlamaları üst yeniden kategorizasyona, Müslüman olan bireyin kendisini Sünni, Şii ya da Alevi olarak tanımlaması alt yeniden kategorizasyona örnek olarak verilebilir.

Dördüncü grup içinde yer alan yeni karşılaştırma grubu, zamansal karşılaştırma ve standartlarla karşılaştırma stratejileri bilişsel, kolektif ve karş1laştırmanın öznesini değiştirmeyi amaçlayan stratejilerdir. Yeni karşılaştırma grubu stratejisi, dezavantajlı grup üyelerinin kendilerini avantajlı grupla karş1laştırmak yerine, daha olumsuz konumda olan bir diğer dezavantajlı grupla karşılaştırmalarıdır. Zamansal karşılaştırma grup üyelerinin farklı gruplarla kıyaslamalar yapmak yerine, kıyaslamayı gruplarının önceki durumuyla yapmaları iken, standartlarla karşılaştırma mevcut durumda kabul edilen standartlarla gerçekleştirilen bir karşılaştırmadır (Blanz ve ark., 1998).

Beşinci ve son grupta yer alan karşılaş̧ırma boyutunun yeniden değerlendirilmesi ve yeni karşılaştırma boyutu stratejileri de bilişsel ve kolektif stratejilerdir, ancak bu stratejilerde amaç karşılaştırma boyutunun değiştirilmesidir. Karşılaştırma boyutunun yeniden değerlendirilmesi grup üyelerinin avantajlı oldukları özelliklerin değerini yükseltmesini ve/veya dezavantajlı oldukları boyutların değerini düşürmesini kapsar. Örneğin, Batı Almanlar ekonomik boyutta Doğu Almanlardan daha iyi olduğundan Doğu Almanların ekonomik boyutun değerini küçümsedikleri görülmüştür (Blanz ve ark., 1998). Yeni karşılaştırma boyutu ise mevcut boyutlar üzerinde gruplar arası karşılaştırma yapıldığında ortaya çıkan olumsuz sonuçları olumluya çevirmek için karşılaştırmanın farklı boyutlar üzerinden gerçekleştirilmesidir. Ekonomik, akademik, politik boyutlarda Batı Almanların gerisinde kalan Doğu Almanlar, sosyal bağlar gibi ek boyutlar ortaya koyarak gruplarının değerini yükseltmeye yönelmișlerdir (Blanz ve ark., 1998).

Tajfel ve Turner'ın (1979) olumsuz kimliğe yöne- lik tepkileri sınıflandırmasının ardından yapılan laboratuvar deneyleri (Ellemers ve Rijswijk, 1997; Ellemers, van Knippenberg, De Vries ve Wilke, 1988) ve gerçek grup araştırmaları (Baysu, 2007; Bobowik, Basabe ve Páez, 2014a; Mummendey, Kessler, Klink ve Mielke, 1999) dezavantajlı grup üyelerinin bireysel hareketlilikten rekabete varan çeşitli stratejileri benimsediklerini ortaya koymuştur. Bu konuda çalışan araştırmacılar kimlik yönetimi stratejilerinin kapsamlı bir listesine ulaşma amacının yanı sıra, bireylerin strateji seçimlerinin ardındaki faktörleri de anlamaya çabalamışlardır. SKK ile 1980'lerde başlayan bu arayış, SMK ve SBK gibi diğer bazı yaklaşımların da eklenmesiyle günümüzde de devam etmektedir.

SKK çerçevesinde hem yapay şekilde oluşturulan hem de gerçek yaşamda var olan gruplarla yapılan çok sayıda çalışmada iç-grupla özdeşleşmenin kimlik yönetim stratejisi tercihinde en önemli yere sahip değişken olduğu görülmüştür (Boen ve Vanbeselaere, 2001; Dumont ve van Lill, 2009; Martiny, Kessler ve Vignoles, 2011). Genel olarak bakıldığında, iç-gruplarıyla düşük düzeyde özdeşleşenler gruplarının alt konumlarından dolayı grup üyeliklerinden hoşnutsuzdurlar ve bireysel hareketlilik için güçlü bir istek ifade ederler. Bunun aksine, iç-gruplarıyla yüksek düzeyde özdeşleşenler gruplarında kalarak iç-grubun konumunu yükseltmek için kolektif stratejilere yönelirler (Kelly, 1990; Mummendey, Klink ve ark., 1999; Niens ve Cairns, 2002).

Etnik grup bağlamında yapılan çalışmalar etnik grupla özdeşleşmenin rekabet ve çatışma eğilimini arttırdığını, ortak bir kimlikle ya da ulusal kimlikle özdeşleşmenin ise bu eğilimleri azalttığını ortaya koymuştur. Örneğin, Avrupa'daki Kürtlerle yapılan bir çalışmada güçlü bir Kürt kimliği kolektif eylem niyetleriyle olumlu ilişkiliyken, güçlü ortak iç-grup kimliği (Avrupalı) olumsuz ilişkilidir (Ufkes, Dovidio ve Tel, 2015). Bir diğer çalışmada da Türkiye'deki Kürtlerden etnik grubuyla özdeşleşenlerin kolektif eylem niyetlerinin yüksek olduğu bulunmuştur (Çakal, Hewstone, Güler ve Heath, 2016).

SMK'nın temel varsayımı, mevcut sosyal düzenlemelerin kişinin kendisinin ya da ait olduğu grubunun ç1karlarına aykırı olduğu koşullarda bile onu meşrulaştırmak için motive olduğu yönündedir (Jost, Banaji ve Nosek, 2004; van der Toorn ve Jost, 2014). Bu kuram, SKK'nın aksine, dezavantajlı gruplarda ego ve grup meşrulaştırma güdülerinden ziyade, sistemi meşrulaştırma güdüsünün baskın olduğunu vurgular. Kurama göre, ego veya grup meşrulaştırma güdülerinin gücü, sistemi meşrulaştırma güdüsünün gücünü aştığında dezavantajlı grup üyeleri sosyal değişimi hedefleyen stratejilere başvururlarken; sistemi meşrulaştırma güdüsünün daha güçlü olması durumunda ise sistemi destekleyen stratejilere başvururlar (Jost ve ark., 2004). SMK çerçevesinde yapılan çalışmalar, mevcut sistem meşru olarak algılandığında dezavantajlı grup 
üyelerinin sosyal değişime direnç gösterdiklerini, sistem yanlısı kolektif eylemleri desteklediklerini ve sistem karşıtı kolektif eylemleri desteklemediklerini ortaya koymaktadır (Brandt ve Reyna, 2012; Osborne, Jost, Becker, Badaan ve Sibley, 2019).

SBK, gruplar arası rekabet ya da çatışmadan çok, dezavantajlı grup üyelerinin avantajlı gruplarla olan işbirliğine odaklanır ve hiyerarşi ve gruplar arası eşitsizliklerin devam etmesinde bireylerin sosyal baskınlık yöneliminin önemli bir faktör olabileceğini ileri sürer. İnsanların grup temelli baskınlığı ve gruplar arasındaki eşitsizliği arzulama ve destekleme eğilimi olarak tanımlanan bu psikolojik değişken (Pratto, Sidanius ve Levin, 2006) sadece sosyo-politik tutum ve davranışta bireysel farklılıkları anlamak için değil, gruplar arası çatışma ve uyuşma süreçlerini anlamak açısından da önemli bir yere sahiptir (Pratto, Sidanius, Stallworth ve Malle, 1994; Sidanius ve Pratto, 1999). Yüksek SBY'ye sahip dezavantajlı grup üyeleri eşitsizlik içeren statükoyu ve avantajlı grubu destekleme eğilimindeyken, düşük SBY'ye sahip dezavantajlı grup üyeleri mevcut hiyerarşiyi değiştirme ve iç-grubu destekleme eğilimindedirler (Henry, Sidanius, Levin ve Pratto, 2005; Levin, Sinclair, Sidanius ve van Laar, 2009). Mevcut literatürde SBY'nin rekabet ve bireysel hareketlilik gibi tepkilerle olan ilişkisini doğrudan ele alan çalışmaların eksikliği göze çarpmaktadır. Bu çalıșma ile kimlik yönetim stratejilerinin SBY ile olan ilişkisini ortaya çıkararak literatüre katkı sağlamayı amaçlamaktayız.

\section{İç-Grup Tarafgirliğine Karşı Dış-Grup Tarafgirliği}

İç-grup tarafgirliği kişinin üyesi olduğu gruba yönelik olumlu tutumlarını ve tercihlerini ifade ederken (Hewstone, Rubin ve Willis, 2004), dış-grup tarafgirliği, kişinin üyesi olmadığı bir dış gruba yönelik olumlu tutumlarını ve o grubu, kendi iç grubunun üzerinde tutma yönündeki tercihini ifade eder (Jost ve ark., 2004). Gruplar arası ilişkiler alanındaki güncel literatür, farklı kuramların, grup davranışlarını açıklamada iç-grup tarafgirliği ya da dış-grup tarafgirliği tercihleri bakımından ayrıldıklarını göstermektedir. Bunlardan SKK'nın iç-grup tarafgirliğine odaklandığ görülürken, SBK ve özellikle de SMK açıklamalarını daha çok dış-grup tarafgirliğinin belirleyici önemine dayandırmaktadır.

SKK'ya göre, iç-grubu kayırma, iç-grubun daha yüksek bir statüyü elde etmesine veya mevcut yüksek statüyü korumasına hizmet eder; böylece iç-grup üyeleri için olumlu bir sosyal kimlik sağlar ve grup üyelerinin benlik saygısını sürdürme ya da arttırma ihtiyaçlarını tatmin eder. Grup üyelerinin iç-grup tarafgirliğine motive olmasını sağlayan en kritik faktör kişinin kendi iç-grubuyla özdeşleşmesidir (Ashburn-Nardo, Knowles ve Monteith, 2003; De Cremer, 2001; Liebkind, Henning-Lindblom ve Solheim, 2006). Şili, Peru, Kolombiya, Venezuela ve ABD'den ör- neklemlerle yapılan geniş ölçekli çalışmalarda ulusal içgrup tarafgirliği için güçlü kanıtlara ulaşılmıştır (Fiedler, Hellmann, Dorrough ve Glöckner, 2018). Öte yandan, çok sayıda etnik grubun içinde bulunduğu belirli bir toplumsal yapıda, bireyler o toplumsal yapıyı temsil eden ulusal kimlikle özdeşleştiklerinde, kendi etnik kimliklerine yönelik olumlu değerlendirmeleri azalmaktadır (Liebkind ve ark., 2006).

SMK, iç-grup tarafgirliği etkisine kuramsal olarak önemli itirazlar getirerek dikkatleri dezavantajlı gruplarda dış-grup tarafgirliğinin yaygınlığına çekmiştir (Jost ve Hunyady, 2002). Kurama göre, dezavantajlı grup üyeleri kendilerine yönelik olarak geliştirilen ve mevcut sosyal sistemi meşrulaştırmaya hizmet eden olumsuz kalıpyargıları ve yüksek statülü gruba yönelik olumlu kalıpyargıları içselleştirir. Bu süreç dezavantajlı gruplarda dış-grup lehine olan bazı tutum ve inançları ortaya çıkarır. Dış-grup tarafgirliği, eşitsiz sistemi içselleştirme ve böylece bu sistemi sürdürme eğiliminin bir tezahürü olarak görülür (Jost ve ark., 2004). SMK, dezavantajlı grup üyelerinin sosyal sistemi adil, meşru ve haklı algıladığı ölçüde iç-gruplarının değerini düşürdüklerini ve diş-grup tarafgirliği sergilediklerini iddia eder (Jost, 2001).

SBK da SMK'ya benzer şekilde dezavantajlı gruplarda dış-grup tarafgirliğinin yaygınlığını vurgulamakta ve bunun mevcut hiyerarşileri koruma işlevi gördüğünü iddia etmektedir. Kuram, hiyerarşik yapının üretilmesine ve sürdürülmesine avantajlı grubun yanı sıra dezavantajlı grubun da önemli bir katkı sağladığını belirtir. Bu durumu davranışsal asimetri olarak tanımlayan kurama göre, avantajlı gruplar kendi çıkarları doğrultusunda davranma eğilimindeyken, dezavantajlı gruplar genellikle kendi çıkarlarına ters düşen davranışlar sergileme eğilimindedir (Pratto ve ark., 2006; Sidanius ve Pratto, 1999). Bu davranışların sergilenmesinde rol oynayan bireysel farklılıklar SBY ile temsil edilir. Kuram, yüksek SBY'ye sahip dezavantajlı grup üyelerinin avantajlı gruplara yönelik diş-grup tarafgirliği sergileyebileceklerini ileri sürer (Sidanius, Pratto, van Laar ve Levin, 2004). Rabinowitz (1999) avantajl1 gruplarda SBY ve iç-grup tarafgirliği arasında olumlu, dezavantajlı gruplarda ise olumsuz ilişki olduğunu göstermiştir. Öte yandan, dezavantajlı gruplarda SBY ve dış-grup tarafgirliği ilişkisi olumlu yöndedir (ayrıca bkz.. Jost ve Thompson, 2000; Levin, Federico, Sidanius ve Rabinowitz, 2002).

Yukarıda aktarılan çalışmalardan da görüleceği üzere, kimlik yönetim stratejileri ve iç- ve dış-grup tarafgirliği genel olarak belirli bir kuram çerçevesinde incelenmiştir. Ancak kuramlardan her biri bu olgulara birbirinden farklı açıklamalar getirmektedir. Kimlik yönetim stratejilerinin ve iç- ve dış-grup tarafgirliğinin daha iyi anlaşılmasında üç kuramın birlikte kullanılması önemli katkılar sağlayabilir. $\mathrm{Bu}$ sebeple bu çalışmada üç kuramın ana değişkenlerini 
eş zamanlı kullanarak kimlik yönetim stratejilerini ve dışgrup tarafgirliğini incelemeyi amaçladık.

\section{Dış-Grup Tarafgirliği ve Örtük Ölçüm}

Bireylerin diş-gruplara yönelik olumlu-olumsuz tutum ve inançlarının öz bildirime dayalı açık ölçümlerle ortaya çıkarılmasındaki zorluklar araştırmacıları alternatif, daha az müdahaleci tutum ölçümlerinin geliştirilmesi için harekete geçirmiştir. Araştırmacılar bu problemin çözümü için örtük ya da dolaylı ölçümler denilen yöntemlere yönelmişlerdir (detaylı bilgiler için bkz. Greenwald, 1990; Korkmaz, 2017). Günümüzde en yaygın kullanılan yöntemlerden biri Greenwald, McGhee ve Schwartz (1998) tarafından geliştirilen Örtük Çağrışım Testi'dir (ÖÇT: Implicit Association Test). Bu test, kişinin davranışlarında otomatik olarak kendini gösteren örtük tutumları ölçmeyi hedefler.

SMK, birçok toplumda bireylerin iç-grup çıkarlarına göre davranmaları gerektiğini vurgulayan normlara maruz kaldıklarını iddia eder. Özellikle toplumsal hiyerarşi içinde alt kademelerde yer alan gruplardaki bireyler, iç-grup tarafgirliği ifade etmeye yönelik bir sosyal baskıyı daha çok hissederler (Jost ve ark., 2004). Kurama göre, dezavantajlı grup üyeleri bilinçli bir düzeyde reddetseler bile, bilinçdışı bir şekilde yüksek statülü gruplara yönelik yanl11ıklara sahip olacaklardır. Araștırmalarda, SMK'nın varsayımlarıyla tutarlı şekilde dış-grup tarafgirliğinin dezavantajlı bir grubun üyesi olan çocuklarda (Dunham, Baron ve Banaji, 2006; Newheiser, Dunham, Merrill, Hoosain ve Olson, 2014) ve yetişkinlerde (Ashburn-Nardo ve Johnson, 2008; Batalha, Akrami ve Ekehammar, 2007; Jost, Pelham ve Carvallo, 2002) yaygın olduğuna yönelik bulgular elde edilmiştir. Kuram dezavantajlı grupların üyeleri için güçlü normatif baskılar bulunduğundan, dış-gruplara yönelik değerlendirmeler için açık ölçümlerden ziyade örtük ölçümlerin kullanılması gerektiğini iddia eder (Jost ve ark., 2004). Mevcut araştırmanın amaçlarından biri bu kuramın pek sınanmamış olan bu iddiasının dezavantajlı bir grup olarak düşünülen Kürt grubuyla incelemektir.

\section{Kimlik Yönetim Stratejileri ve Dış-Grup Tarafgirliği}

Dezavantajlı grupların neden iç- ya da dış-grup tarafgirliği sergilediğine yönelik olarak Scheepers, Spears, Doosje ve Manstead (2006) iç-grup tarafgirliğinin kimlik ve araçsal olmak üzere iki işlevinden bahseder. Kimlik işlevinde, iç-grup yanlılığı olumlu, farklı ve anlamlı bir sosyal kimlik yaratmaya ve ifade etmeye hizmet ederken; araçsal işlevde, iç-grup yanlılığı belirli hedeflerin başarılmasını kolaylaştırır. İç-grup yanlılığı özellikle gruplar arası rekabeti ve sosyal değişimi kolaylaştırmak gibi iki grup hedefine hizmet edebilir. Rubin, Badea ve Jetten (2014) yaptıkları iki çalışmada dezavantajlı grup üyelerinin (a) mevcut eşitsizliği telafi etmek ve (b) gelecekte yüksek bir statü için rekabet etmek amacıyla iç-grup tarafgirliği gösterdiklerini bulmuşlardır. Bu sonuçlar, dezavantajlı grup üyelerinin kendi gruplarını yüksek statülü dış-grup kadar iyi veya yüksek statülü dış-gruptan daha iyi yapmak için iç-grup tarafgirliği sergilediklerini ortaya koymaktadır. Benzer şekilde, dış-grup tarafgirliğinin de olumlu bir kimlik edinme amacıyla sergilendiği söylenebilir. Dış-grup tarafgirliği yüksek statülü grup üyeliğini kazanmak (örn. bireysel hareketlilik) için kullanılabilir ve kişisel hedeflere hizmet edebilir. Mevcut çalışmada henüz sınanmayan bu iddianın dış-grup tarafgirliğinin kimlik yönetim stratejileriyle olan ilişkisi üzerinden incelemesi amaçlanmıştır.

\section{Kimlik Yönetim Stratejileri ve Kimlikle İlgili Eylem ve Hedefler}

Dezavantajlı grup üyelerinin benlik saygılarını olumsuz etkileyen önyargılı ve ayrımcı tavırlarla başa çıkabilmek için bir takım çabalar içine girdikleri bilinen bir olgudur (Verkuyten, 1998). Crocker ve Major (1989) çok sayıda çalışmayı inceleyerek damgalanan grup üyelerinin çeşitli stratejiler benimseyerek benlik kavramını koruyabildiklerini ve benlik saygılarını yükseltebildiklerini göstermişlerdir. Bobowik ve arkadaşları (2014a, 2014b) İspanya'da yaşayan farklı etnik gruptan göçmenlerle yaptıkları çalışmalarda kimlik yönetim stratejilerinin hem psikolojik hem de sosyal iyi oluş ile ilişkili olduğunu bulmuşlardır. Kimlik yönetim stratejilerinin psikolojik işleyiş üzerinde koruyucu bir etkisinin olduğu gösterilmesine rağmen, bunların gerçek hayatta bireylerin kimlikleriyle ilgili eylem ve hedefleri ile ne türden ilişkiye sahip oldugu ihmal edilmiş bir konudur. Bu çalışmada söz konusu stratejilerin bireylerin etnik gruplarıyla bağlantılı davranışlarını ve amaçlarını ne ölçüde belirlediği ele alınmaktadır. Bu çalışmada kimlikle ilgili eylemler bireyin etnik kimliğini yansıtan ve onu güçlendiren davranışları, kimlikle ilgili hedefler ise bireyin etnik kimliğini kültürel ve ekonomik olarak yansitacak ve destekleyecek eylemleri içeren gelecek planları olarak kavramsallaştırılmıştır.

\section{Türkiye'deki Kürtler}

Ulusal kimlikten farklı bir kimliğe sahip olmanın, bir sosyal grup için dezavantaj yaratan birkaç koşuldan biri olmasının yanı sıra, dezavantajlı grup üyelerinde olumsuz kimlikle başa çıkma açısından farklı tepkiler üretme potansiyeline de sahip olduğu bilinmektedir. Türkiye'deki Kürt kimliğinin de böyle bir duruma uygun bir örnek olduğu söylenebilir. Ulusal kimliğin çeşitli boyutlarının Türk ve Kürt etnik grup üyeleri için farklılaştığı, ulusal kimlikle özdeşleşen Kürtlerin Türklere benzer, kendi etnik kimlikleriyle özdeşleşenlerin ise daha farklı değerlendirmelere sahip oldukları bildirilmektedir (Bilali, 2014; Çelebi, Verkuyten, Köse ve Maliepaard, 2014; Çoymak, 2018). Ayr1ca, Kürtlerin Türklere oranla ulusal kimlikle daha düşük 
düzeyde özdeşleşirken etnik kimlikle daha yüksek düzeyde özdeşleştiği; Türklerde etnik ve ulusal kimlikler arasında olumlu yönde güçlü bir ilişki varken Kürtler içinse böyle bir ilişkinin söz konusu olmadığı yönünde bulgulara rastlanmaktadır (Bağcı ve Çelebi, 2017; Bilali, 2014).

Grup içi ve gruplar arası ayrışmaların toplumsal ve siyasal koşullardan önemli ölçüde etkilendiği bilinen bir gerçektir. Göregenli (2015) tarafindan Kürtlerin yoğun olarak yaşadığı Diyarbakır'da yapılan bir araştırmada, şiddet ve işkence olaylarına ilişkin bilgi ve duyumların bireylerin sistemi meşrulaştırma eğilimlerini azalttı̆̆ı, adil dünya inançlarını zayıflattığı ve şiddete karşı harekete geçme düşüncelerini güçlendirdiği saptanmıştır. Dezavantajlı grup üyelerinin kimlik yönetme stratejilerindeki çeşitliliği arttıran bir diğer neden de hızlı sosyo-yapısal değişimlerdir. Son kırk yıla yayılan bir dönemde, çok sayıda Kürt, bölgede yaşanan çatışmalara da bağlı olarak İstanbul, Ankara, İzmir, Bursa ve Adana gibi büyük şehirlere göç etmiştir. Metropollerde toplumsal yaşama katılmanın zorluklarıyla başa çıkmaya çalışan Kürtler, bir yandan da son yıllarda giderek daha da şiddetlenen bir önyargı ve ayrımcıllkla yüz yüze kalmışlardır (BILLGESAM, 2014; Yıldırım, Turhan ve Kuşdil, 2020). Böylesi bir süreç sonunda Türkiye'deki Kürtler, etnik temelli siyaset yaparak kimlik haklarını elde etmeye çalışanlardan, Türklere benzer tercih ve değerlendirmelere sahip olanlara dek uzanan bir çeşitlilik sergileyen bir grup haline gelmiştir (Ergil, 2009; Uluğ, Odağ, Cohrs ve Holtz, 2017). Kısacası, rekabetten sosyal hareketliliğe, Türkiye'deki Kürt kimliği, dezavantajlı bir grubun farklı kimlik yönetim stratejilerinin ayrıntılı bir sosyal psikolojik analizi için nadir rastlanılacak bir örnek niteliği taşımaktadır.

\section{Çalışmanın Amacı ve Hipotezler}

$\mathrm{Bu}$ çalışmanın amacı, dezavantajlı grup üyelerinin olumsuz bir sosyal kimlikle nasıl başa çıtıkları ve ne tür tepkiler sergilediklerini kimlik yönetim stratejileri ve dışgrup tarafgirliği kapsamında incelemektir. Çalışmamızda, SKK, SBK ve SMK'nın ana değişkenleri olan etnik özdeşleşme, SBY ve sistemi meşrulaştırmanın diş-grup tarafgirliği ve kimlik yönetim stratejileri ile ilişkileri Kürt erkek üniversite öğrencilerinden oluşan bir örneklemde ele alınmıştır. Ayrıca, bahsedilen değişkenlerin Kürtlerin etnik kimliğiyle ilgili eylemleri ve gelecekteki amaçları belirleyip belirlemediği karşılaştırmalı olarak incelenmiştir.

Araştırmanın amaçları kapsamında üç model test edilmiştir. Bunlardan ilki stratejilerin etnik kimlikle ilgili davranışları ve geleceğe yönelik planları belirleyip belirlemediğini ortaya çıkarmak için oluşturulmuştur. Bu modelde kimlik yönetim stratejileri yordayıcı değişkenler, kimlikle ilgili eylem ve hedefler bağımlı değişkenler olarak ele alınmıştır. Bu model yoluyla sınanacak hipotez aşağıdaki gibidir:

1) Bireysel ve bilișsel stratejileri benimseyen dezavantajlı grup üyelerinin etnik gruplarıyla bağlarını koparma eğiliminde oldukları dikkate alındığında bu bireylerin etnik gruplarının temel özelliklerini yansitan eylem ve hedefleri daha az benimseyecekleri; rekabet stratejilerini benimseyen üyelerinse etnik grubun kimliğini temsil eden davranışlara ve amaçlara daha fazla yönelecekleri beklenmektedir.

İkinci modelde, üç kuramın ana değişkenleri ilk modele eklenerek analiz edilmiştir. Bu model ile hem stratejilerin hem de kimlikle ilgili eylem ve hedeflerin belirleyicilerinin ortaya konması amaçlanmıştır. Modelde, yukarıda aktarılan literatür doğrultusunda, etnik kimlikle özdeşleşme, sistemi meşrulaştırma ve SBY yordayıcı değişkenler, kimlik yönetim stratejileri aracı değişkenler ve kimlikle ilgili eylem ve hedefler bağımlı değişkenler olarak analiz edilmiştir.

2) 2a. Etnik kimlikle özdeşleşme düzeyi arttıkça rekabet stratejilerinin, azaldıkça ise bireysel ve bilişsel stratejilerin kullanımı artacaktır.

2b. Etnik kimlikle özdeşleşme düzeyi arttıkça etnik kimlikle ilgili eylemlerde bulunma ve hedeflere sahip olma yükselecektir.

3) 3a. Sistemi meşrulaştırma düzeyi yüksseldikçe bireysel ve bilişsel stratejilerin, azaldıkça ise rekabet stratejilerinin kullanımı artacaktır.

3b. Sistemi meşrulaştırma düzeyi yükseldikçe etnik eylemlerde bulunma ve hedeflere sahip olma azalacaktır.

4) 4a. SBY düzeyi yükseldikçe bireysel ve bilişsel stratejilerin, azaldıkça ise rekabet stratejilerinin kullanımı artacaktır.

4b. SBY yükseldikçe etnik kimlikle ilgili eylemlerde bulunma ve hedeflere sahip olma azalacaktır.

Son modelde ise, ikinci modele açık ve örtük dişgrup tarafgirlikleri de eklenerek bu kez tüm değişkenler arasındaki ilişkiler tek bir modelde sınanmıştır. Bu model sayesinde diş-grup tarafgirliğinin hem belirleyicileri hem de stratejilerle olan ilişkileri incelenmiştir. Ayrıca, model, kimlikle ilgili eylem ve hedefleri yordayan en güçlü değişkenlerin hangileri olduğunu saptamada da fayda sağlamıştır. Modelde, yine mevcut literatür ışığında, etnik kimlikle özdeşleşme, sistemi meşrulaştırma ve SBY yordayıcı değişkenler, açık ve örtük dış-grup tarafgirliği ile kimlik yönetim stratejileri aracı değişkenler ve kimlikle ilgili eylem ve hedefler bağımlı değişkenler olarak ele alınmıştır.

5) 5a. Etnik kimlikle özdeşleşme düzeyi arttıkça dişgrup tarafgirliği azalacaktır.

5b. Sistemi meşrulaştırma düzeyi arttıkça dış-grup tarafgirliği artacaktır.

5c. SBY yükseldikçe dış-grup tarafgirliği artacaktır. 5d. Diş-grup tarafgirliği yükseldikçe bireysel ve bilişsel stratejilerin, azaldıkça ise rekabet stratejilerinin kullanımı artacaktır.

5e. D1ş-grup tarafgirliği yükseldikçe, etnik kimlikle 
Tablo 1. Ölçeklere ve Modellere Ait Uyum İndeksleri

\begin{tabular}{lccccccc}
\hline Ölçek & $\chi 2$ & df & $\chi 2 /$ df & GFI & CFI & RMSEA & SRME \\
\hline Etnik özdeşleşme & 61.72 & 34 & 1.81 & .91 & .91 & & .08 \\
Sistemi meşrulaştırma eğilimi & 48.34 & 32 & 1.51 & .93 & .90 & .06 & .06 \\
Sosyal baskınlık yönelimi & 117.75 & 88 & 1.34 & .89 & .93 & .05 & .07 \\
Kimlikle ilgili eylemler & 23.96 & 14 & 2.03 & .94 & .94 & .09 & .06 \\
Kimlikle ilgili hedefler & 25.07 & 9 & 2.03 & .94 & .94 & .01 & .05 \\
Açık dış-grup tarafgirliği & 35.96 & 19 & 1.89 & .93 & .93 & .09 & .06 \\
Kimlik yönetim stratejisi (ilk 18 madde) & 144.85 & 121 & 1.20 & .90 & .96 & .04 & .06 \\
Kimlik yönetim stratejisi (12 strateji) & 74.06 & 47 & 1.58 & .92 & .92 & .07 & .07 \\
Kimlik yönetim stratejisi (9 strateji) & 43.27 & 21 & 2.06 & .93 & .93 & .09 & .07 \\
Model 1 & 2.49 & 1 & 2.49 & .99 & .99 & .11 & .05 \\
Model 2 & .25 & 1 & .25 & 1 & 1 & .00 & .01 \\
Model 3 & 6.34 & 3 & 2.11 & .99 & .99 & .09 & .02 \\
\hline
\end{tabular}

ilgili eylemlerde bulunma ve hedeflere sahip olma azalacaktır.

Son modelde kimlik yönetim stratejileri ile açık ve örtük dış-grup tarafgirliği değişkenlerden hangilerinin arac1 rol oynadığını belirlemek amacıyla bir araştırma sorusu oluşturulmuştur:

S1) Hangi değişkenler etnik kimlikle özdeşleşme, sistemi meşrulaştırma ve SBY ile kimlikle ilgili eylem ve hedefler arasında aracı rol oynamaktadır?

\section{Yöntem}

\section{Örneklem ve İşlem}

Araştırmaya, Bursa Uludağ Üniversitesi'nin çeşitli bölümlerinde eğitim gören ve kendini Kürt kimliğiyle tanımlayan 125 erkek öğrenci katılmıștır. Kartopu örneklem tekniği kullanılarak ulaşılan katılımcıların yaşları 18 ile 28 arasında değişmektedir $(\mathrm{Ort} .=22.66 ; S S=2.09)$. Ayrıca, katılımcıların politik yönelimlerini belirlemek amacıyla "Politik görüss olarak kendinizi nerede konumlandirırstnlz?" sorusu sorulmuș ve bu soru 1 (așirl sol) ile 7 (așırı sağ) arası Likert tipi bir ölçeklendirme yöntemi ile değerlendirilmiştir $($ Ort. $=3.72 ; S S=1.21)$.

Araştırma, 2016-2017 öğretim yılı güz döneminde, üniversite kampüsündeki Psikoloji Bölümü Laboratuvarı'nda iki aşamalı olarak gerçekleștirilmiștir. Katılımcılar gönüllü onam formunu imzaladıktan sonra önce tüm ölçeklerin yer aldığı anket formunu yanıtlamışlar, ardından, bilgisayar üzerinde kendilerine ÖÇT uygulanmıştır. Veri toplama aşaması her katılımcıyla bireysel şekilde yürütülmüş, oturumların ortalama tamamlanma süresi yaklaşık 45 dakikayı bulmuştur.

\section{Veri Toplama Araçları}

SBY ve örtük dış-grup tarafgirliği ölçümü dışında, bu çalışmada kullanılan tüm ölçek maddeleri 5'li Likert tipi skalalarla ölçülmüsşür $(1=$ Hiç katılmıyorum; $5=$ Tamamen katıllyorum).

Sistemi Meşrulaştırma Eğilimi. Mummendey, Klink ve arkadaşları (1999) tarafindan sosyo-yapısal değişkenleri ölçmek için geliştirilen ve Baysu (2007) tarafından Türkçeye uyarlanan ölçek, bu çalışmada sistemi meşrulaştırma eğilimini ölçmek amacıyla kullanılmıştır. Ölçek gruplar arasındaki statü farkının geçirgenlik, kalıcılık ve meşruluk boyutlarını ölçen 10 maddeyi içermektedir. Ölçek maddeleri gruplar arası sınırların nasıl algılandığıyla ilgili ayrıntılı bir inceleme şansı sunduğundan, etnik gruplarla ilgili sistemi meşrulaştırma eğilimini değerlendirmek için kullanılmasına karar verilmiştir. Yaptı̆̆ımız Doğrulayıcı Faktör Analizi (DFA) sonucunda, üç faktörlü ölçüm modelinin veriye iyi bir uyum gösterdiği saptanmıştır (tüm ölçeklere ait uyum indeksleri Tablo 1'de sunulmaktadır). Tüm ölçek maddeleri gruplar arasındaki statü farkının değerlendirmesini hedeflediğinden, bu çalışmada tümünün ortalamasından hareketle tek bir değişken olarak (sistemi meşrulaştırma eğilimi) analizlere dâhil edilmiştir. Ancak, tüm maddeler için güvenirlik katsayısı hayli düşüktür $(\alpha=.46)$. Gerek Baysu'nun (2007) yaptığı uyarlama çalıșmasında gerekse de diğer çalışmalarda bu ölçeğe ait alt boyutların iç güvenirlik katsayılarının düşük olduğu göz önüne alınarak ilgili literatürde yaygın biçimde kullanılan bu ölçekten elde ettiğimiz puanların değerlendirilmesine karar verilmiştir. 
Etnik Grupla Özdeşleşme. Kürt katılımcıların etnik gruplarılla ne düzeyde özdeşleştiklerini belirlemek için, Roccas (2003) tarafından geliştirilen ve Ceylan ve Özbal (2008) tarafindan Türkçeye uyarlanan 10 maddelik ve tek boyutlu Özdeşleşme Ölçeği kullanılmıştır $(\alpha=.82$; örn. "Kendi etnik kökenimden olan herkesle kuvvetli bağlarım olduğunu hissederim"). DFA sonucu tek faktörlü ölçüm modelinde başarılı bir uyum indeksi gözlenmiş̧ir.

Sosyal Baskınlık Yönelimi. Pratto ve arkadaşlarının (1994) 16 maddelik ölçeği ( $\mathrm{SDO}_{6}$ ) kullanılmıştır. Orijinali tek boyuttan oluşan ve 7'li Likert skala üzerinden değerlendirilen ölçek aynı şekilde kullanılmışırı $(1=$ Çok yanlış; $7=$ Çok doğru ). Ölçek Türkçeye ilkin tek boyutlu olarak uyarlanmış (Karaçanta, 2002), ancak yakın zamanda iki boyutlu olarak revize edilmiștir (Hasta ve Karaçanta, 2017). Ölçeğin "İstediğinizi elde etmek için bazen diğer gruplara karşı zor kullanmak gereklidir" maddesi Uludağ Üniversitesi Sosyal ve Beşeri Bilimler Araştırma ve Yayın Etik Kurulu tarafindan uygun görülmediği için ölçekten çıkarılmıștır. Çalıșmada kullanılan 15 maddenin iki faktörlü ölçüm modelinin iyi bir uyuma sahip olduğu görülmüştür. Çalışmaların büyük çoğunluğunda tek boyutlu olarak kullanılan ölçek, bunlarla tutarlı olması amacıyla bu çalışmada da tek boyut olarak analizlere dâhil edilmiștir $(\alpha=.78)$.

Açık Dıș-Grup Tarafgirliği. Kürt katılımcıların Türk grubuna yönelik açık dış-grup tarafgirliği Güler (2013) tarafindan geliştirilen tek boyutlu, 8 maddelik ölçek yoluyla ölçülmüştür (örn. "Türk kökenli grubu değerli bulurum"). Ölçekten alınan puan yükseldikçe Türklere yönelik tarafgirlik de artmaktadır. Yapılan DFA, tek faktörlü modelin veri ile iyi bir uyum içerisinde olduğunu ortaya koymaktadır $(\alpha=.78)$.

Örtük Dıș-Grup Tarafgirliğĭ. Örtük dış-grup tarafgirliğini ölçmek için Greenwald ve arkadaşları (1998) tarafından oluşturulan ÖÇT kullanılmıştır. Test, iki hedef grubu (örneğin, Siyah-Beyaz) ve nitelik belirten kelimeler (olumlu-olumsuz) arasındaki ilişkiyi değerlendirmektedir. Test kapsamında katılımcılara iki hedef grubuna ait uyaranlar (resimler ya da isimler) sunulur ve katılımcılardan bu uyaranları mümkün olduğunca hızlı şekilde klavye üzerindeki "E" ve "I" tuşlara basarak nitelik belirten kelimelerle eşleştirmeleri istenir.

Bu çalışmada, ÖÇT kapsamında Türk ve Kürt hedef gruplarını temsil etmek için 8 Türkçe ve 8 Kürtçe isim olmak üzere 16 isim kullanılmıştır. Söz konusu isimler bir ön çalı̧̧ma yoluyla belirlenmiştir. İsimleri belirleme amacıyla, öncelikle, sosyal medya üzerinden ulaşılan kişilerden akıllarına gelen üçer Kürt, üçer de Türk erkek ve kadın ismi yazmaları istenmiştir. Önerilen isimler, verilen cevapların sıklığına göre sıralanmıştır. Ayrıca çeşitli internet kaynaklarından yapılan tarama- lardan da isimler belirlenmiştir. Bu şekilde saptanan dokuzar Kürtçe, dokuzar da Türkçe erkek ve kadın ismi olmak üzere, toplam 36 isimlik liste, her ismin yanına 7'li Likert tipi skala yerleştirilerek ( $1=$ Türk ismi ve 7 $=$ Kürt ismi) derecelendirilmiştir. Bu liste, kendilerini Kürt olarak tanımlayan 161 üniversite öğrencisine çevrimiçi olarak sunulmuştur. Ön çalışma sonucunda Asena, Öykü, Göktürk, Alper gibi isimlerin Türk hedef grubunu; Berîtan, Rojda, Bawer, Neçîrvan gibi isimlerin Kürt hedef grubunu temsil edebileceklerine karar verilmiştir. Nitelik boyutunu temsil eden kelimeler ise Greenwald ve arkadaşları (1998) tarafindan kullanılan kelime listesinden seçilmiştir. Sağlik, huzur, dost, mutluluk, zevk, günışı̆̆ , gökkuşağı, mucize olumlu kelimeleri oluştururken; acı, cinayet, pislik, hastalık, ölüm, kaza, zehir, felaket ise olumsuz kelimeleri oluşturmaktadır. Bu çalışma kapsamında ÖÇT "Inquisit 4 Lab" adlı bilgisayar programından yararlanılarak oluşturulmuştur. Program, test sonuçların yorumlanması için kullanılan D puanı$\mathrm{n}$ i otomatik olarak hesaplar. D puanı $-2 \mathrm{ve}+2$ arasında değişmektedir. Bu çalışmada ÖÇT'de -2 'ye yaklaşan puanlar Kürtlere yönelik tarafgirliği (örtük iç-grup tarafgirliği), +2 'ye yaklaşan puanlar ise Türklere yönelik tarafgirliği (örtük dış-grup tarafgirliği) göstermektedir.

Kimlik Yönetim Stratejileri. Blanz ve arkadaşları (1998) tarafindan olușturulan Kimlik Yönetim Stratejileri Ölçeği (KYSÖ) katılımcıların dezavantajlı kimliklerine yönelik tepkilerini incelemek için kullanılmıştır. Ölçeğe ait tüm maddelerin (12 strateji için 35 madde) Türkçeye uyarlanmasının ardından, yapı geçerliği analizleri Blanz ve arkadaşları'nın (1998) izledikleri sıraya göre yapılmıştır. Önce ölçeğin ilk 18 maddesinin, ardından da elde edilen tüm stratejilerinin güvenirlik ve geçerlik analizleri yapılmış ve 1) bireysel hareketlilik, 2) asimilasyon, 3) sosyal rekabet, 4) gerçekçi rekabet ve 5) bireyselleşme stratejilerini ölçen ilk 18 madde üzerinden gerçekleștirilen DFA sonucunda beş faktörlü ölçüm modeli başarılı bir uyum indeksi göstermiştir (bkz. Tablo 1). On iki strateji ayrı ayrı hesaplandıktan sonra, tüm stratejiler orijinal çalışmadaki beş faktör yapısına göre modele dâhil edilmiştir. Beş faktörlü modelin uyum düzeyi kabul edilebilir olsa da, dördüncü boyutu oluşturan karşılaştırma boyutunu yeniden değerlendirme ile yeni karşılaş̧tırma boyutu stratejileri ve beşinci boyutta yer alan yeni karşılaş̧tırma grubu stratejisinin çok düşük düzeyde faktör yükü aldıkları saptanmıştır (faktör yükleri sırasıyla $.17, .34, .15)$. Dolayısıyla, bu üç strateji analizden çıkarılarak geri kalan stratejiler 4 boyut üzerinden modele dâhil edilmiştir. Analiz sonucunda, içinde 9 stratejinin yer aldığ gözlenmiştir (bkz. Tablo 1). Sosyal rekabet ile gerçekçi rekabet stratejileri rekabet; bireysel hareketlilik ile asimilasyon stratejileri hareketlilik; bireyselleşme, üst 
Tablo 2. Ortalamalar, Standart Sapmalar ve Değişkenler Arasındaki Korelasyonlar $(N=125)$

\begin{tabular}{|c|c|c|c|c|c|c|c|c|c|c|c|}
\hline & Ort. (SS) & 1 & 2 & 3 & 4 & 5 & 6 & 7 & 8 & 9 & 10 \\
\hline 1. Rekabet & $3.46(.77)$ & & & & & & & & & & \\
\hline 2. Hareketlilik & $1.58(.58)$ & -.14 & & & & & & & & & \\
\hline 3. Kategorizasyon & $1.20(.78)$ & $-.49^{* * *}$ & $.33^{* * *}$ & & & & & & & & \\
\hline 4. Karşılaştırma & $.72(.69)$ & $-.18^{*}$ & -.09 & $.24^{* *}$ & & & & & & & \\
\hline 5. Özdeşleşme & $3.59(.65)$ & $.56^{* * *}$ & -.09 & $-.49^{* * *}$ & -.17 & & & & & & \\
\hline $\begin{array}{l}\text { 6. Sistemi meşrulaştırma } \\
\text { eğilimi }\end{array}$ & $2.57(.46)$ & $-.30^{* *}$ & $.36^{* * *}$ & $.42^{* * *}$ & .09 & $-.30^{* * *}$ & & & & & \\
\hline 7. Sosyal baskınlık yönelimi & $2.12(.73)$ & -.13 & $.27^{* *}$ & $.21^{*}$ & -.05 & -.14 & .11 & & & & \\
\hline 8. Örtük dış-grup tarafgirliği & $.00(.42)$ & $-.35^{* * *}$ & $.18^{*}$ & $.41^{* * *}$ & .09 & $-.31^{* * * *}$ & $.30^{* *}$ & .10 & & & \\
\hline 9. Açık dış-grup tarafgirliği & $3.00(.67)$ & $-.45^{* * *}$ & $.36^{* * *}$ & $.50^{* * * *}$ & .14 & $-.41^{* * * *}$ & $.40^{* * * *}$ & .07 & $.37^{* * * *}$ & & \\
\hline 10. Kimlikle ilgili eylemler & $3.66(.75)$ & $.44^{* * * *}$ & $-.26^{* *}$ & $-.50^{* * * *}$ & -.09 & $.61^{* * *}$ & $-.35^{* * *}$ & $-.18^{*}$ & $-.52^{* * *}$ & $-.57^{* * *}$ & \\
\hline 11. Kimlikle ilgili hedefler & $3.99(.68)$ & $.48^{* * * *}$ & $-.29^{* * *}$ & $-.49^{* * *}$ & -.10 & $.58^{* * * *}$ & $-.43^{* * *}$ & -.12 & $-.48^{* * *}$ & $-.64^{* * * *}$ & $.76^{* * * *}$ \\
\hline
\end{tabular}

$*_{p}<.05,{ }^{* *} p<.01, * * * p<.001$.

yeniden kategorizasyon ile alt yeniden kategorizasyon stratejileri kategorizasyon ve zamansal karşılaştırma ile standartlarla karşılaştırma stratejileri ise karşılaştırma stratejileri olarak adlandırılmıştır (sırasıyla $\alpha=.75, .80$, .71 ve .75).

Kimlikle İlgili Eylemler. Yedi maddelik bu ölçek, Kürt üniversite öğrencilerinin etnik kimliklerini yansıttığ1 düşünülebilecek anadilini konuşmak, anadilde müzik dinlemek gibi birtakım davranışları ne düzeyde sergilediklerini incelemek amacıyla bu çalışma kapsamında yazarlar tarafından geliştirilmiştir. Yapılan DFA sonucunda tek faktörlü yapının veriye iyi bir uyum gösterdiği sap$\operatorname{tanmıştır~}(\alpha=.83)$.

Kimlikle İlgili Hedefler. Katılımc1ların etnik kimlikleriyle ilgili etnik grubunun haklarını savunan toplumsal projelerde yer almak, anadilini çocuklarına ögrretmek gibi gelecekte neler yapmayı planladıklarını incelemek amacıyla altı maddelik bu ölçeği oluşturduk. DFA, tek boyutlu modelin başarılı bir uyum sergilediğini göstermektedir $(\alpha=.78)$.

\section{Bulgular}

\section{Korelasyon Analizleri}

Araştırmada kullanılan değişkenler arasındaki korelasyonlar Tablo 2'de gösterilmektedir. Hipotez 2a ve 5 a'da önerildiği gibi, etnik grupla özdeşleşme rekabet stratejileri ile olumlu $(r=.56, p<.001)$, kategorizasyon stratejileri ile olumsuz $(r=-.49, p<.001)$ ve açık ve örtük dış-grup tarafgirliği ile olumsuz (sırasıyla, $r=-.41$, $p<.001 ; r=-.31, p<.001$ ) yönde ilişkiler göstermiştir. Ancak, etnik grupla özdeşleşme ve hareketlilik stratejileri arasında anlamlı bir ilişki yoktur $(r=-.09, p=.335)$. Sistemi meşrulaştırma, rekabet ile olumsuz $(r=-.30, p$ $<.001)$, hareketlilik $(r=.36, p<.001)$ ve kategorizasyon $(r=.42, p<.001)$ stratejileriyle ile olumlu ilişkiler göstermesinin yanı sıra, açık ve örtük dış-grup tarafgirliğiyle (sırasıyla, $r=.40, p<.001 ; r=.30, p<.001$ ) de olumlu ilişkiler sergileyerek hipotez 3 a ve 5 b'yi desteklemiştir. SBY ile hareketlilik $(r=.27, p=.002)$ ve kategorizasyon $(r=.21, p=.021)$ stratejileri arasinda olumlu yönde ilişkiler gözlenirken, rekabet stratejileri arasında anlamlı bir ilişkiye rastlanmamaktadır $(r=$ -.13, $p=.137)$. Varsaydığımız, ancak, desteklenmeyen ilişkilerden biri (Hipotez 5c), SBY'nin açık ( $r=.07, p$ $=.467)$ örtük $(r=.10, p=.284)$ diş-grup tarafgirliğiyle anlamlı bir ilişki sergilememiş olmasıdır. Öte yandan, beklediğimiz gibi (hipotez $5 \mathrm{~d}$ ) hem açık hem de örtük dış-grup tarafgirliği rekabet stratejileriyle (sırasıyla, $r=$ $-.45, p<.001 ; r=-.35, p<.001)$ olumsuz bir ilişkiye; hareketlilik (sırasıla, $r=.36, p<.001 ; r=.18, p$ $=.046$ ) ve kategorizasyon (sirasiyla, $r=.50, p<.001$; $r=.50, p<.001$ ) stratejileriyle ise olumlu bir ilişkiye sahip olduğu bulunmuştur. Stratejilerden yalnızca karşılaştırma stratejileri hiçbir değişkenle anlamlı bir ilişki göstermemiştir. 
Hipotez 1'de beklenildiği gibi rekabet stratejileri kimlikle ilgili eylem $(r=.44, p<.001)$ ve hedeflerle ( $r=.48, p<.001)$ olumlu yönde ilişkiler gösterirken, hareketlilik ve kategorizasyon stratejileri kimlikle ilgili eylem (sirasiyla, $r=-.26, p=.003 ; r=-.50, p<.001$ ) ve hedeflerle (sirasiyla, $r=-.29, p=.001 ; r=-.49, p<$ .001 ) olumsuz yönde ilişkiler göstermiştir. Kimlikle ilgili eylem ve hedeflerin, ayrıca, etnik kimlikle özdeşleşme ile olumlu, sistemi meşrulaştırma, açık ve örtük dış-grup tarafgirliği ile olumsuz ilişkili olduğu gözlenmiştir. Ancak, kimlikle ilgili eylem ve hedeflerle en güçlü ilişkileri etnik özdeşleşme ile açık ve örtük dış-grup tarafgirliği sergilemiştir (bkz. Tablo 2).

\section{Yol Analizleri}

Yol analizleri AMOS 23.0 programı kullanılarak gerçekleştirilmiştir. Yol analizlerinde sınanan modellerin veri ile uyum gösterip göstermediğini değerlendirmek için karşılaştırmalı uyum indeksi (comparative fit index, CFI), uyum iyiliği indeksi (goodness of fit index, GFI), yaklaşık hatanın ortalama karekökü (root mean square error of approximation, RMSEA) ve standardize edilmiş kalıntıların ortalama karekökü (standardized root mean square residual, SRMR) indeksleri temel alınmıştır. Literatürde bu indekslerin sunduğu değerlerin önemi üzerinde tam bir uzlaşma bulunmasa da, başarılı bir uyum gösteren modele ulaşabilmek ya da model üzerinde araştırmaya devam edebilmek için, indeks değerlerinin RMSEA ve SRMR için .10'u geçmemesi; CFI ve GFI'ın .90 'dan büyük ya da yakın olması ve son olarak Ki kare değerinin serbestlik derecesine oranının $(\chi 2 / \mathrm{sd}) 5$ 'den büyük olmaması yönünde görüşler bulunmaktadır (bkz.. Schermelleh-Engel, Moosbrugger ve Müller, 2003). Dolayısıyla, modellerle ilgili kararlar yukarıda belirtilen indeks değerleri üzerinden verilmiştir.

Çalışmanın amaçlarıyla bağlantılı olarak hazırlanan modeller aşamalı olarak test edilmiştir. Korelasyon analizleri sonucunda karşılaştırma stratejileri hiçbir değişkenle anlamlı bir ilişki göstermediğinden modellere dâhil edilmemiştir. İlkin stratejilerin kimlikle ilgili eylem ve hedefler üzerindeki etkilerini ortaya çıkarmak için oluşturulan Model 1 yol analizi aracılığıyla incelenmiştir. Uygulanan ölçüm modeli veri ile başarılı bir uyum sergilemiştir. Tüm modellere ait uyum indeksleri Tablo 1'de verilmiştir.

Stratejiler ile kimlikle ilgili eylem ve hedefler arasındaki ilişkilerin test edildiği modelin sonuçlarına göre (bkz. Şekil 1), rekabet stratejilerini benimsemek etnik temelli eylemlerde bulunmayı ve hedeflere sahip olmay1 olumlu yönde yordarken (s1rasiyla $\beta=.27, p=.002 ; \beta$ $=.32, p<.001$ ), kategorizasyon stratejilerini benimsemek ise etnik temelli eylemlerde bulunmayı ve hedeflere sahip olmayı olumsuz yönde yordamıştır (sırasıyla $\beta=$
$-.34, p<.001 ; \beta=-.29, p<.001)$. Hareketlilik stratejilerini benimsemek ise sadece daha az etnik temelli eylemlerde bulunmayı yordamıştır $(\beta=-.15, p=.048)$.

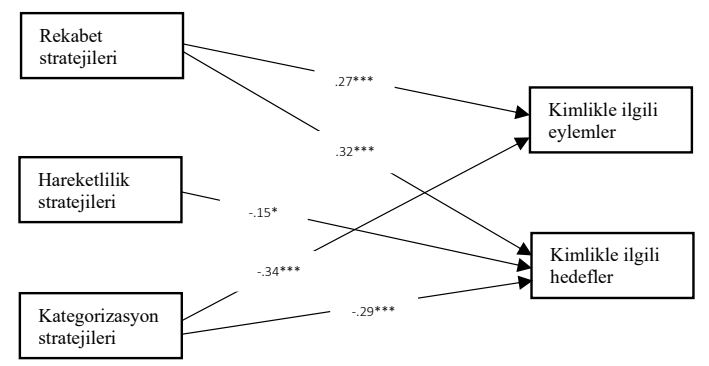

Not. Şekilde görülen bütün yollar istatistiki olarak anlamlıdır, $*_{p}<.05, * * p<.01, * * * p<.001$.

Şekil 1. Kimlik Yönetim Stratejileri ile Kimlikle ilgili Eylem ve Hedefler Arasındaki İlişkiler İçin Model 1.

Kimlik yönetim stratejilerinin eylem ve hedef üzerindeki etkilerinin incelenmesinin ardından, kuramları temsil eden değişkenlerin etkilerini saptamak amaciyla bu modele etnik özdeşleșme, sistemi meşrulaştırma ve SBY eklenerek oluşturulan Model 2 test edilmiştir. Bu ölçüm modelinin veri ile çok başarılı bir uyum indeksi sergilediği gözlenmiştir (bkz. Tablo 1).

Model 2'nin analiz sonuçlarına göre (bkz. Şekil 2), bağımsız değişkenler ile stratejiler ve kimlikle ilgili eylem ve hedef arasında öngörülen ilişkilerin çoğu desteklenmiştir. Örneğin, Hipotez $2 \mathrm{a}$ 'da belirtildiği gibi, etnik grupla yüksek düzeyde özdeşleşme rekabet stratejilerini kullanmayı olumlu yönde yordarken $(\beta=.51, p<.001)$, kategorizasyon stratejilerini kullanmayı olumsuz yönde yordamıştır $(\beta=-.38, p<.001)$. Fakat etnik grupla özdeşleşme ile hareketlilik stratejileri arasında anlamlı bir ilişki gözlenmemiştir $(\beta=.05, p=.531)$. Beklediğimiz gibi (Hipotez 3a) sistemi yüksek düzeyde meşrulaştırma hareketlilik ve kategorizasyon stratejilerini kullanmayı olumlu yönde yordarken (sirasıly $\beta=.35, p<.001 ; \beta=.29, p<$ $.001)$, rekabet stratejilerini kullanmayı ise olumsuz yönde yordamıştır $(\beta=-.14, p=.067)$. Desteklenmeyen hipotezlerin çoğunun SBY'ye ait olduğu anlaşılmaktadır. Bunlardan biri de (Hipotez 4b) SBY'nin kimlikle ilgili eylem ve hedeflerle anlamlı bir ilişki sergilememiş olmasıdır (sirasiyla, $\beta=-.03, p=.640 ; \beta=.04, p=.575$ ). SBY'deki artışlar sadece hareketlilik stratejilerini daha fazla kullanmayı anlamlı düzeyde yordamaktadır $(\beta=.24, p=.004)$.

Dikkat çekici sonuçlardan biri, etnik grupla özdeşleşme, SBY ve sistemi meşrulaştırma değişkenlerinin modele dâhil edilmesiyle stratejilerin eylem ve hedefleri doğrudan yordama güçlerinin yok olması ya da azalmasıdır. Örneğin, modelde etnik grupla yüksek düzeyde öz- 


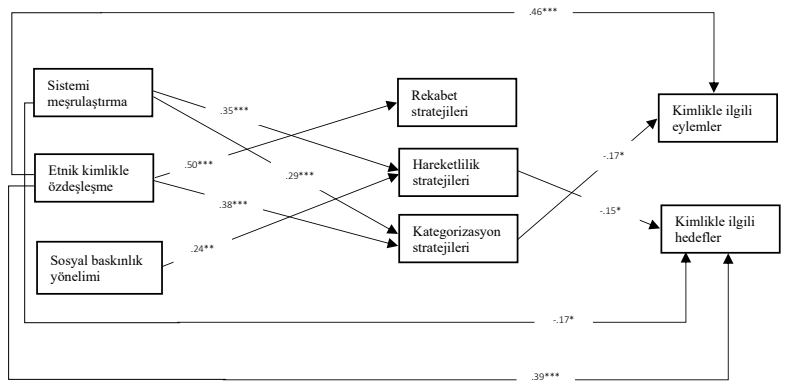

Not. Şekilde görülen bütün yollar istatistiki olarak anlamlıdır, $* p<.05, * * p<.01, * * * p<.001$.

Şekil 2. Sistemi Meşrulaştırma, Etnik Özdeşleşme ve Sosyal Baskınlık Yönelimi Değişkenlerinin Analize Eklendiği Model 2.

deşleşme kimlikle ilgili eylemlerde bulunmayı $(\beta=.46$, $p<.001)$ ve hedeflere sahip olmay1 $(\beta=.39, p<.001)$ olumlu yönde yordarken (Hipotez $2 b$ ), sistemi yüksek düzeyde meşrulaştırma ise kimlikle ilgili hedeflere sahip olmayı ( $\beta=-.17, p=.029)$ olumsuz yönde yordamıştır (Hipotez 3b). Ancak, rekabet stratejilerini tercih etmenin kimlikle ilgili eylemlerde bulunmayı $(\beta=.06, p=.452)$ ve hedeflere sahip olmay1 $(\beta=.13, p=.111)$ anlamlı yordama gücü ortadan kalkmıştır. Ayrıca, kategorizasyon stratejilerini tercih etmenin kimlikle ilgili hedeflere daha az sahip olmayı anlamlı yordama gücü kaybolurken $(\beta=$ $-.13, p=.126)$, kimlikle ilgili eylemlerde daha az bulunmay1 yordama gücü de düşmüştür $(\beta=-.17, p=.045)$. Sistemi yüksek düzeyde meşru görmenin kimlikle ilgili hedeflere sahip olmayı olumsuz yönde yordaması $(\beta=$ $-.17, p=.029$ ) Hipotez 3b'nin bir k1smını desteklerken, kimlikle ilgili eylemlerde bulunmayı anlamlı biçimde yordamaması $(\beta=-.07, p=.356)$ bu hipotezin diğer k1smını desteklememiştir.

Son olarak, açık ve örtük dış-grup tarafgirliğinin eklenmesiyle tüm değişkenlerin olduğu Model 3 test edilmiștir. Tablo 1'de görüldüğü gibi, bu model de diğerleri gibi veri ile başarılı bir uyum sergilemiştir. Değişkenler arasındaki ilişkiler Şekil 3'de verilmiştir. Model 3'e ait yol katsayıları ise Tablo 3'de görülebilir.

Açık ve örtük dış-grup tarafgirliğinin eklenmesiyle etnik özdeşleşmenin ve sistemi meşrulaştırma değişkenlerinin stratejileri yordama güçleri azalsa da tümüyle ortadan kalkmamıştır. Beklendiği gibi (Hipotezler 5a ve $5 b)$, etnik grupla yüksek düzeyde özdeşleşme hem açık $(\beta=-.32, p<.001)$ hem de örtük $(\beta=-.23, p=.008)$ dişgrup tarafgirliği sergilemeyi olumsuz yönde yordarken; sistemi meşrulaştırma hem açık $(\beta=.31, p<.001)$ hem de örtük $(\beta=.23, p=.010)$ diş-grup tarafgirliği sergilemeyi olumlu yönde yordamaktadır. Ancak, beklenenin

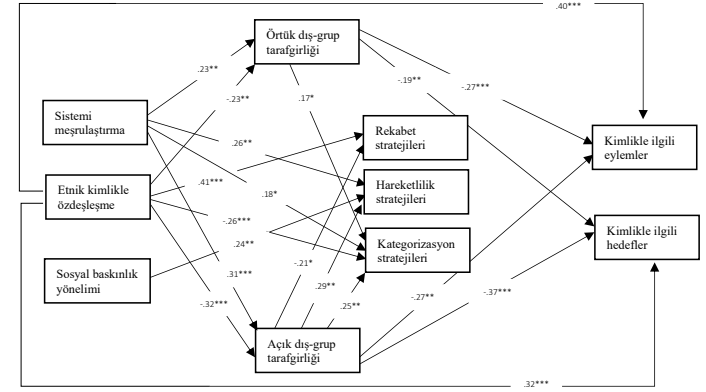

Not. Şekilde görülen bütün yollar istatistiki olarak anlamlıdır, $* p<.05, * * p<.01, * * * p<.001$

Şekil 3. Tüm Değişkenlerin Yer Aldığı Model 3.

aksine (Hipotez 5c), SBY ne açık $(\beta=-.01, p=.859)$ ne de örtük $(\beta=.04, p=.649)$ diş-grup tarafgirliğini anlamlı yordamaktadır.

Açık ve örtük dış-grup tarafgirliği değişkenleri kimlik yönetim stratejileriyle anlamlı ilişkiler göstermenin yanı sıra, hem kimlikle ilgili eylemleri (sırasıyla, $\beta$ $=-.27, p<.001 ; \beta=-.28, p<.001)$ hem de kimlikle ilgili hedefleri (sırasıyla, $\beta=-.37, p<.001 ; \beta=-.19, p=$ .004 ) olumsuz şekilde yordamaktadır. Model 2'yle ilgili bulgularda olduğu gibi, etnik özdeşleşme, kimlikle ilgili eylem ve hedefleri güçlü biçimde yordamaya devam etmiştir. İlginç bir diğer sonuç da, açık ve örtük dış-grup tarafgirliğinin modele eklenmesiyle stratejilerin kimlikle ilgili eylem ve hedeflerle olan ilişkilerinin ortadan kalkmasıdır. Model 2'de etnik grupla özdeşleşme rekabet stratejisinin kimlikle ilgili eylem ve hedefleri yordama gücünü ortadan kaldırırken; Model 3'te dıș-grup tarafgirliği hareketlilik ve kategorizasyon stratejilerinin yordama gücünü ortadan kaldırmaktadır. Ayrıca, sistemi meşrulaştırmanın da kimlikle ilgili hedeflerle olan ilişkisi ortadan kalkmaktadır.

Aracı değişkenlerin dolaylı etkilerinin istatistiksel anlamlılığına bakıldığında, etnik özdeşleşmenin ve sistemi meşrulaştırmanın sadece açık ve örtük dış-grup tarafgirliği üzerinden kimlikle ilgili eylem ve hedefleri yordadığ1 görülmüştür (bkz. Tablo 3). Buna göre, etnik kimlikle düşük düzeyde özdeşleşme ve sistemi meşru algılama dış-grup tarafgirliği sergileme üzerinden kimlikle ilgili eylemlerde bulunmayla ve kimlikle ilgili hedeflere sahip olmayla ilişkili olmuştur.

\section{Tartışma ve Sonuç}

$\mathrm{Bu}$ araştırma, Türkiye'de yaşayan Kürtlerin dezavantajlı sosyal kimliğe yönelik tepkilerinin ve etnik 


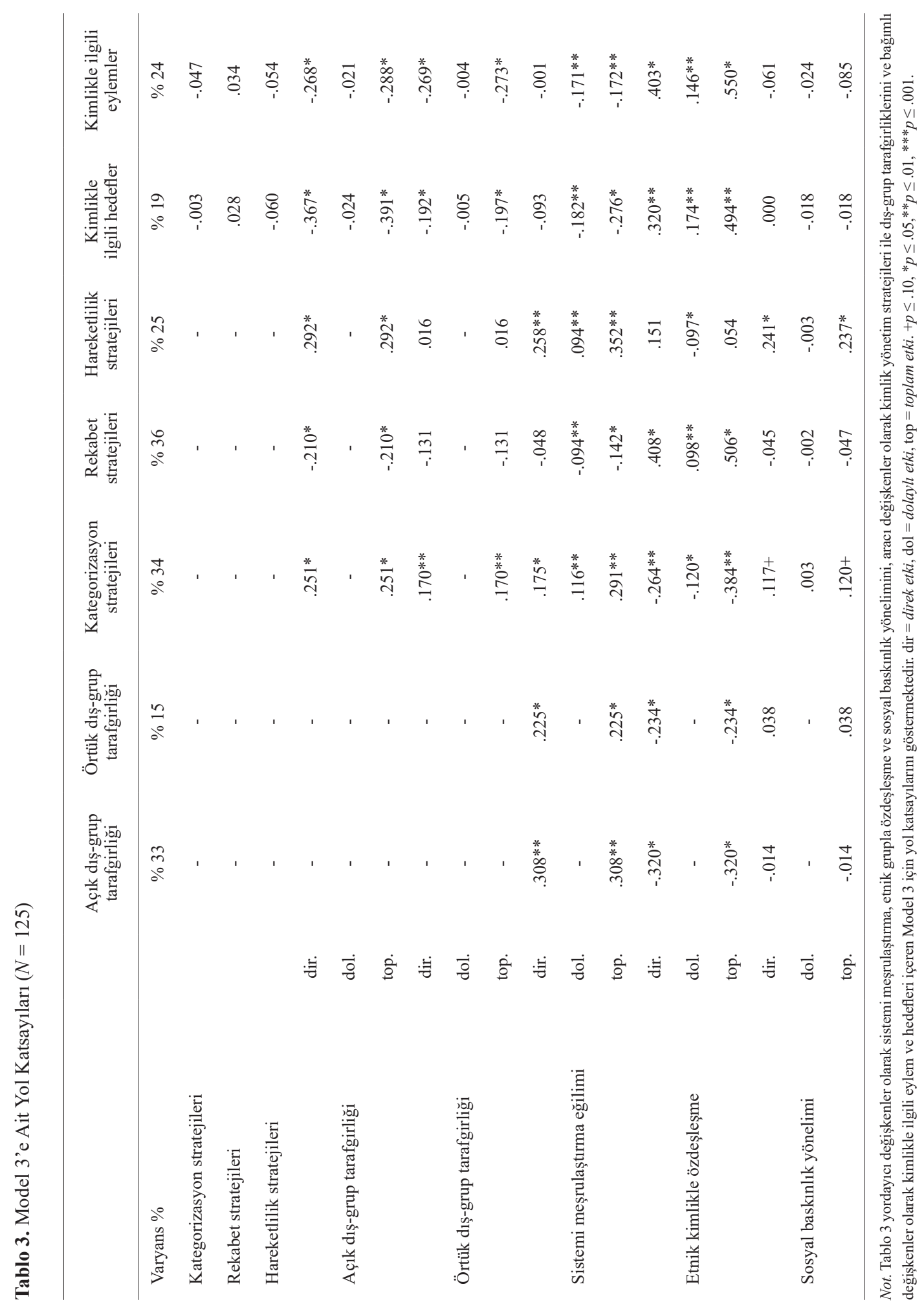


kimlikleriyle ilgili mevcut davranışlarının ve gelecekle ilgili düşüncelerinin altında yatan faktörlerin neler olduğunu saptamak amacıyla gerçekleştirilmiştir. Araştırma kapsamında ilk olarak stratejilerin kimlikle ilgili eylem ve hedefler ile ilişkili olup olmayacağı sorusuna cevap aranmıştır. Korelasyon ve yol analizleri sonucunda rekabet stratejilerinin kimlikle ilgili eylem ve hedeflerle olumlu, hareketlilik ve kategorizasyon stratejilerinin ise söz konusu değişkenlerle olumsuz yönde ilişkili olduğu saptanmıştır. Rekabet stratejilerinin temel amacı sosyal değişimi gerçekleştirmek iken, hareketlilik ve kategorizasyon stratejilerinin amacı gruplar arasındaki çatışmayı azaltmak ve avantajlı grupla uyumlu bir şekilde yaşamay1 sağlamaktır (Becker, 2012; Hogg ve Abrams, 1998). Dolayısıyla, bulgularımıza dayanarak rekabet stratejilerini benimseyen Kürtlerin hareketlilik ve kategorizasyon stratejilerini benimseyenlerden farklı olarak, etnik kimliklerini yansıtan davranışlar sergiledikleri ve etnik kimlikleri ile ilgili geleceğe dönük hedefler belirledikleri anlaşılmaktadır. Bulgular, stratejilerin sadece bireysel düzeyde algılar olarak kalmadıklarını ve bu stratejilerin kimlikle ilgili davranışlarla ve düşüncelerle yakından ilişkili olduklarını göstermesi açısından önem taşımaktadır.

Araştırmada yanıt aranan bir diğer soru da stratejilerin ve dış-grup tarafgirliğinin belirleyicilerinin neler olduğu sorusudur. Strateji tercihini ve diş-grup tarafgirliğini belirleyen en güçlü değişkenin SKK'ya ait etnik grupla özdeşleşme olduğu saptanmıştır. Bu bulgu, kolektif eylem ve gruplar arası rekabet üzerine yapılan çalışmalarla da paralellik göstermektedir (Moghaddam, Taylor ve Lalonde, 1987; Wright, 2009). İç-grupla özdeşleşmenin rekabet stratejileriyle olumlu yönde ilişkili olduğunu gösteren çok sayıda çalışma bulunmaktadır (örn. Ellemers ve Rijswijk, 1997; Kessler ve Mummendey, 2002; Martiny ve ark., 2011). Kürt etnik grubuyla yapılan çalışmalar da etnik kimlikle özdeşleşmenin kolektif eylemi anlamada önemli bir bileşen olduğunu net bir biçimde ortaya koymaktadır (Çakal ve ark., 2016; Ufkes ve ark., 2015). Bu araştırma etnik özdeşleşmenin, kolektif eylem olgusunun ötesinde, Kürtlerin kimliklerini yönetme tarzlarını nasıl belirlediğini göstermesi açısından mevcut literatüre katkı sağlamaktadır.

Etnik özdeşleşme ve kimlik yönetme stratejileri arasındaki ilişkilere dair bir diğer önemli bulgu da, etnik özdeşleşme düzeyinin bireyselleşme, üst ve alt yeniden kategorizasyon stratejilerinin yer aldığ kategorizasyon stratejileriyle olumsuz yönde bir ilişkiye sahip olmasıdır. Dezavantajlı bir grup üyeliği kişinin benlik saygısı üzerinde olumsuz bir etkiye neden olacağından, grup üyeleri kendilerini gruplarından psikolojik olarak ayırmaya çalışır (Blanz ve ark., 1998). Böylece, bireyler kendilerini olumsuz görülen bir sosyal grubun üyesi olarak görmek yerine, değerli kişisel özelliklere sahip bağımsız bir kişi olarak görerek benlik saygısını koruyabilir (Branscombe ve Ellemers, 1998). Kürt kimliğiyle özdeşleşme düzeyi düşük olan bireylerin bireyselleşme stratejisini tercih etmeleri bu açıklamalar 1şı̆̆ında anlaşılabilir.

Mevcut araştırmada, üst yeniden kategorizasyon stratejisi bireyin kendisini ne düzeyde Türkiye Cumhuriyeti vatandaşı gördüğü açısından ele alınmıştır. Bu kapsamda, Kürt kimliğiyle özdeşleşme arttıkça Kürt gençlerinin kendilerini Türkiye Cumhuriyeti vatandaşı olarak tanımlama eğilimleri azalmaktadır. Benzer bir sonuç, Kürtlerin kendilerini ortak kimlik olan "Avrupalılık" üzerinden tanımlama düzeyleri ile etnik özdeşleşmeleri arasında da gözlenmiştir (Ufkes ve ark., 2015). Bayad ve Kuşdil (2011) tarafından yapılan çalışmada Kürt öğrencilerin Türk kimliğini bir üst kimlik olarak kullanma olasılıklarının düşük olduğu saptanmıştır.

Desteklenmeyen hipotezlerden biri hareketlilik stratejileri (asimilasyon ve bireysel hareketlilik) ile etnik özdeşleşme arasındaki olumsuz ilişsi ile ilgilidir. Literatürle uyuşmayan bu bulgu Türkiye bağlamında birkaç nedenden dolayı ortaya çıkmış olabilir. Bunlardan ilki, araştırmanın örneklemini oluşturan Kürtler arasında asimilasyonun hoş karşılanmıyor olmasıdır; dolayısıyla, böyle bir çalışmada asimilasyon eğilimi olanlar bile söz konusu norm nedeniyle bunu belirtmekten çekinmiş olabilirler. İkinci neden ise, katılımcıların tamamının üniversite öğrencilerinden oluşmasıdır. Etnik kimliklerin hayli belirgin olabildiği bir bağlam olarak üniversiteler Kürt öğrencilerin politize olmasında etkin bir rol oynayarak onları kendi kimliklerine daha sıkı bağlanmaya yöneltebilir. Bireysel hareketliliğin neredeyse imkânsız olduğu, ırka dayalı hiyerarşilere odaklanan bazı çalışmalarda, dış-grup tarafgirliği hareketlilik stratejisinin bir parçası olarak kullanılmıştır (Dumont ve van Lill, 2009). Bizim çalışmamızda da etnik grupla özdeşleşme azaldıkça dış-grup tarafgirliğinin arttığ 1 gözlenmiş, bireysel hareketlilik stratejilerinden elde edilemeyen sonuçlara dış-grup tarafgirliği üzerinden ulaşılmıştır. Bu bulgular, Türkler ve Kürtler gibi birbirinden farklı etnik grupların kıyaslandığı çalışmalarda, hareketlilik stratejilerine yönelik ölçümlerden ziyade, dış-grup tarafgirliğinin daha belirleyici olabileceğini göstermektedir.

$\mathrm{Bu}$ çalışmada elde edilen sonuçlar, SMK'nın varsayımıyla tutarlı olarak, mevcut sosyal yapının meşru ve adil olduğu inancının yüksek olmasının Kürtlerin uyuşmaya yönelik tepkiler sergilemelerine yol açtığını göstermiştir. Dezavantajlı etnik gruplarla yapılan farklı çalışmalarda meşruluk algısının benzer mekanizmalara hizmet ettiği görülmüştür (Baysu, 2007; Jost, Kivetz, Rubini, Guermandi ve Mosso, 2005; Mana, Sagy, Srour ve Mjally-Knani, 2015). Ayrıca, sistemi meşrulaştırma eğilimi arttıkça dış-grup tarafgirliğinin arttığına yönelik 
güçlü bir ilişkinin saptanmış olması, SMK'nın sistemi meşru algılayan bireylerin avantajlı gruba yönelik tarafgirlik sergileyeceği savını da desteklemektedir (Jost ve ark., 2004). Statükonun meşru olmadığı algısı dezavantajlı grup üyelerinin grup bilincini geliştirmelerine ve topluca hareket etmelerine yol açmaktadır. Kürtler arasında mağduriyet algısının ve düzeltilmesi gereken bir adaletsizliğin bulunduğu düşüncesinin kolektif eylemlerin ortaya çıkışında önemli bir rol oynadığı (Çağlayan, 2014) göz önüne alındığında, sistemi meşrulaştırmanın rekabet stratejileriyle olumsuz, hareketlilik ve kategorizasyon stratejileriyle ise olumlu ilişkiler gösteriyor olması daha anlaşı1ır hale gelmektedir.

SBY yüksek olan dezavantajlı grup üyelerinin, avantajlı grubun bir üyesi olma amaciyla statükoyu koruma ve destekleme eğilimine sahip olacakları yönündeki iddiayla tutarlı olarak (Sidanius ve Pratto, 1999), bu araştırmada da SBY'nin sadece hareketlilik stratejileriyle olumlu yönde bir ilişki sergilediği saptanmıştır. Öte yandan, SBY ile rekabet stratejileri arasında öngörülen bağlantılar desteklenmemiștir. Bulgular Hortaçsu'nun (2007, s. 195) yukarıda da sözü edilen, SBY'nin toplumsal değişimi açıklamadaki yetersizliğiyle ilgili çıkarımını destekler niteliktedir. Ancak, bu sonuçlar Kürt etnik grubunun Türkiye'deki dezavantajlı konumuyla ve katılımcıların özellikleriyle de açıklanabilir. SBK, avantajlı gruplara kıyasla, dezavantajlı gruplarda SBY'nin daha düşük olduğunu iddia eder (Pratto ve ark., 2006). Türkiye'de Türk, Kürt, Çerkez ve Laz etnik gruplarıyla yapılan çalışmalarda Kürt etnik grubunun diğer üç etnik gruba k1yasla düşük seviyede SBY'ye sahip olduğu saptanmıştır (Karaçanta, 2002). Diğer yandan, çalışmamızın örnekleminin, eğitimlerinin de etkisiyle eşitliğe ve insan haklarına daha duyarlı üniversite öğrencilerinden oluşması SBY'nin öngörülen etkisinin ortaya çıkmasını engellemiş olabilir. SBY'nin etkileri, dezavantajlı gruplardan ziyade, avantajlı gruplar üzerinde açıkça görülebilmektedir (Levin ve ark., 2012, 2009; Rabinowitz, 1999). Bursa'da çoğunluğu Türk olan işverenlerle yapılan bir çalışmanın, SBY arttıkça Kürtlere yönelik sosyal mesafenin arttığını ve iş başvurusunda bulunan Güneydoğulu adayları işe alma olasılı̆ı̆ının azaldığını ortaya koyması (Yıldırım ve ark., 2020) bu iddiayı destekler niteliktedir.

Mevcut araştırmada yanıtlanmaya çalışılan bir başka soru da, kimlikle ilgili eylem ve hedefler üzerinde stratejilerin mi yoksa diğer değişsenlerin mi daha etkili olduğu sorusudur. Bu nedenle, yol analizlerinde değişkenler sırayla farklı modellere dâhil edilmiștir. İlk modelde stratejilerin kimlikle ilgili eylem ve hedefler üzerindeki etkileri açıkça görülürken, üç kuramın ana değişkenlerinin (etnik grupla özdeşleşme, sistemi meşrulaştırma ve SBY) dâhil edildiği ikinci modelde hareketlilik ve kategorizasyon stratejilerinin güçleri kayda değer biçimde azalmış, rekabet stratejilerinin kimlikle ilgili eylem ve hedefler üzerindeki yordama gücü ise ortadan kalkmıştır. Son modele açık ve örtük dış-grup tarafgirliğinin eklenmesiyle birlikte hareketlilik ve kategorizasyon stratejilerinin eylem ve hedef üzerindeki yordayıcı güçleri de ortadan kalkmaktadır. Sonuncu modelde kimlikle alakalı eylem ve hedefleri yordamada en etkili değişken etnik özdeşleşme iken, ikinci etkili değişken dış-grup tarafgirliği olmuştur. Bu bulgu SKK'nın (ve iç-grupla özdeşleşmenin) gruplar arası ilişkilerle bağlantılı süreçleri açıklamada ne kadar değerli olduğunu bir kez daha göstermektedir.

Bir diğer önemli bulgu da, açık ve örtük dış-grup tarafgirliklerinin kimlikle ilgili eylem ve hedefleri yordama gücünün kimlik yönetimi stratejilerinden de yüksek olması ve bunların her ikisinin de Kürt katılımcıların hedef/eylem yönelimi çeşitliliğini yordamada aynı yönde etkili olmasıdır. Analiz sonuçları, açık ve örtük dış-grup tarafgirliklerinin birbirleriyle yakından ilişkili olduğunu ve benzer sonuçlara yol açtı̆̆ını göstermektedir. Ancak, SMK'nın varsayımının aksine, açık dış-grup tarafgirliğinin diğer değişkenleri yordamada örtük ölçümden daha güçlü olduğu bulunmuştur. Bu bulgu uzun yillar bir arada yaşayan gruplardan dezavantajlı olanın açık bir şekilde dış-grup tarafgirliği sergileyebileceğinin bir göstergesi olarak kabul edilebilir.

\section{Gruplararası İlişkileri İyileştirmek için Öneriler}

$\mathrm{Bu}$ araşıırmanın bulguları 1şığında, gruplararasındaki rekabet ve çatışmaların azaltılması için birkaç öneride bulunulabilir. Bulgular, Kürtlerin etnik kimlikleriyle ilgili hedef ve eylemlere verdikleri önemin özellikle rekabet içeren stratejilere yönelmeleriyle arttığını göstermektedir. Rekabet stratejilerinin yüksek düzeyde benimsenmesi ise grupla yüksek düzeyde özdeşleşmeyle ilişkilidir. Dolayısıyla, çatışma olasılığını arttıran rekabet stratejilerinin kullanımının hangi koşullarda azalacağı belli gibidir: Kürtleri kendi kimliklerine doğru çekilme refleksine zorlayan toplumsal, siyasal ve ekonomik koşulların iyileştirilmesi bir çözüm olarak önerilebilir. Çeşitli toplumsal gruplara yönelik önyargı ve ayrımcılığın azaltılması, toplumsal meşruiyet algılarının güçlendirilmesine yönelik politikaların geliştirilerek uygulanması bu kapsamda yararlı olacaktır. Kürt kimliğiyle alakalı sosyo-kültürel olanakların (örn., Kürtçenin kullanımı ve öğretimi) daha da genişletilmesi bu kapsamda uygulanabilecek politikalara örnek olarak verilebilir. Saleem ve Ramasubramanian (2017) tarafindan yapılan çalışmada olumsuz medya temsillerine maruz bırakılan ve ayrımcılık algılayan Müslüman Amerikalı öğrencilerin ABD toplumundaki Müslüman imajını değiştirmek için kolektif eylemlere yöneldiklerini ve Müslüman olmayan Amerikalılardan uzak durmayı tercih ettiklerini göstermesi yukarıda öneriler için bir kanıt olarak görülebilir. 


\section{Sinırlılıklar}

$\mathrm{Bu}$ araştırmanın güçlü yönleriyle birlikte bazı s1nırlılıkları da mevcuttur. Çalışmanın en önemli sınırlılığ yalnızca Bursa'daki üniversite öğrencileriyle yapılmış olmasıdır. Öğrencilerden elde edilen bulguların değişik yaş gruplarından bireylere ve daha az eğitimli olmaları nedeniyle düşük düzeyde politize olanlara genellemesinin güçlükler yaratacağ1 açıktır. Özellikle de, kimlik yönetim stratejileri gibi, toplumsal yaşam içinde kimliğe yönelik tehditlere karşı üretilen tepkilerin ele alındığı bir çalışmada böyle bir sınırlılık strateji çeşitliliğini tam anlamıyla incelemeyi engelleyebilir.

Çalışmanın bir diğer önemli sınırlılığı ise, verilerin sadece erkek öğrencilerden toplanmasıdır. Uludağ Üniversitesi'nde okuyan Kürt kadın öğrencilerinin az sayıda olması çalışmanın erkeklerle yürütülmesini zorunlu kılmıştır. Her ne kadar cinsiyet farklılıkları üzerinde durmanın betimleyici bir faaliyet olduğu ve davranışların açıklamasına ek bir katkı sağlamadığ1 yönünde görüşler bulunsa da (örn. Dökmen, 2015, s. 188), bu çalışmadaki bulguları kadınlara genellemede sorunlarla karşılaşılacağ1 açıktır. Özellikle de, kadınların yüksek oranda katıld1ğ siyasal hareketlerin gerçekleştiği Kürt kimlik grubunda (bkz. Çağlayan, 2014) bu sınırlılık iyice belirgin hale gelmektedir.

Sonuç olarak, mevcut çalışma, üç büyük kuramın ana değişkenlerinin Kürt üniversite öğrencilerinin dezavantajlı kimliğe yönelik tepkilerinin ve etnik kimlikleriyle ilgili eylem ve hedeflerinin anlaşılmasına katkı sağlayabileceğine işaret etmektedir. SKK, sosyal değişimle bağlantılı değișkenlerin güçlü yordayıcısı olurken, SMK ve SBK ise gruplar arası uyuma hizmet eden değişkenlerin güçlü yordayıcıları olmuştur. Bilindiği gibi, SKK genel olarak gruplar arası çatışmalar üzerinde durmakta ve bu çatışmalar altında yatan mekanizmalarla ilgilenmektedir. SMK ve SBK ise gruplar arasındaki uyum ve mevcut toplumsal düzenlerin kendilerini yeniden üretme ve bu düzenleri sürdürme süreçlerine yönelik açıklamalar getirmektedir. Rekabet stratejileri sosyal değişimi gerçekleştirmeyi amaçlarken, hareketlilik ve kategorizasyon stratejileri ile dış-grup tarafgirliği gruplar arasındaki çatışmayı azaltmakta ve avantajlı grupla uyumlu bir şekilde yaşamayı sağlamaktadır. Rekabet stratejilerinin benimsenmesinin etnik kimliği yansıtan eylem ve hedeflere yönelme eğilimini arttırması, hareketlilik ve kategorizasyon stratejileri ve dış-grup tarafgirliğinin ise bu türden eğilimleri azaltması bu görüşü destekleyen bulgulardır. Araştırmamızda ele alınan kuramların her birinin farklı stratejileri açıklamada öne çıkıyor olması, bu kuramların birlikte ele alınmasının önemine işaret etmektedir.

\section{Kaynaklar}

Ashburn-Nardo, L. ve Johnson, N. J. (2008). Implicit outgroup favoritism and intergroup judgment: The moderating role of stereotypic context. Social Justice Research, 21(4), 490-508. doi:10.1007/ s11211-008-0078-8

Ashburn-Nardo, L., Knowles, M. L. ve Monteith, M. J. (2003). Black Americans' implicit racial associations and their implications for intergroup judgment. Social Cognition, 21(1), 61-87. doi:10.1521/ soco.21.1.61.21192

Bağcı, S. Ç. ve Çelebi, E. (2017). Etnik ve ulusal kimlikler ile diş grup tutumları ilişkisinde çatışma algısı ve diş gruba sorumluluk yükleme. Türk Psikoloji Dergisi, 32(80), 63-74.

Batalha, L., Akrami, N. ve Ekehammar, B. (2007). Outgroup favoritism: The role of power perception, gender, and conservatism. Current Research in Social Psychology, 13(4), 38-49.

Bayad, A. ve Kuşdil, M. E. (2011). Kimlik yönetme stratejileri, grupla özdeşleşme düzeyi ve sosyal baskınlık yönelimi arasındaki ilişki: Kürt üniversite öğrencileri örneği. 18. Ulusal Psikoloji Kongresi, Bursa.

Baysu, G. (2007). The Effects of intergroup perceptions and ingroup identifications on the political participation of the second-generation Turkish migrants in the Netherlands. Yayınlanmamış doktora tezi, Orta Doğu Teknik Üniversitesi, Ankara.

Becker, J. C. (2012). The system-stabilizing role of identity management strategies: Social creativity can undermine collective action for social change. Journal of Personality and Social Psychology, 103(4), 647-662. doi:10.1037/a0029240

Bilali, R. (2014). The downsides of national identification for minority groups in intergroup conflicts in assimilationist societies. British Journal of Social Psychology, 53(1), 21-38. doi:10.1111/bjso.12012

BİLGESAM. (2014). Türkiye'de etnik, dini ve siyasi kutuplaşma. (17.07.2018 tarihinde http://www.bilgesam.org/Images/Dokumanlar/0-262-2014081511kutuplasma-anketi_rapor. pdf adresinden alınmıştır.)

Blanz, M., Mummendey, A., Mielke, R. ve Klink, A. (1998). Responding to negative social identity: A taxonomy of identity management strategies. European Journal of Social Psychology, 28, 697729. doi:10.1002/(SICI)1099-0992(199809/10)28: 5<697::AID-EJSP889>3.0.CO;2-

Bobowik, M., Basabe, N. ve Páez, D. (2014a). "Heroes of adjustment": Immigrant's stigma and identity management. International Journal of Intercultural Relations, 41, 112-124. 
Bobowik, M., Basabe, N. ve Páez, D. (2014b). Identity management strategies, perceived discrimination, and well-being among young immigrants in spain. R. Dimitrova, M. Bender ve Fons van de Vijver (Ed.), Global perspectives on well-being in immigrant families içinde (ss. 213-234). New York, NY: Springer Science+Business Media.

Boen, F. ve Vanbeselaere, N. (2001). Individual versus collective responses to membership in a low-status group: The effects of stability and individual ability. Journal of Social Psychology, 141(6), 765783. doi:10.1080/00224540109600587

Brandt, M. J. ve Reyna, C. (2012). Social dominance or system justification? The acceptance of inequality and resistance to social change as unique system-relevant motivations. SSRN Electronic Journal. doi:10.2139/ssrn.2165690

Branscombe, N. R. ve Ellemers, N. (1998). Coping with group-based discrimination: Individualistic versus group-level strategies. J. K. Swim ve C. Stangor (Ed.), Prejudice: The target's perspective içinde (ss. 243-266). San Diego, CA: Academic Press.

Çağlayan, H. (2014). Analar, yoldaşlar, tanrıçalar: Kürt hareketinde kadınlar ve kadın kimliğinin oluşumu (5. bask1). İstanbul: İletişim Yayınları.

Çakal, H., Hewstone, M., Güler, M. ve Heath, A. (2016). Predicting support for collective action in the conflict between Turks and Kurds: Perceived threats as a mediator of intergroup contact and social identity. Group Processes \& Intergroup Relations, 19(6), 732-752. doi:10.1177/1368430216641303

Çelebi, E., Verkuyten, M., Köse, T. ve Maliepaard, M. (2014). Out-group trust and conflict understandings: The perspective of Turks and Kurds in Turkey. International Journal of Intercultural Relations, 40, 64-75. doi:10.1016/j.ijintrel.2014.02.002

Ceylan, A. ve Özbal, S. (2008). Özdeşleşme yoluyla sadakat oluşturma üzerine üniversite mezunları arasında yapılan bir çalışma. C.Ü. İktisadi ve Iddari Bilimler Dergisi, 9(1), 81-110.

Clark, K. B. ve Clark, M. P. (1947). Racial identification and preference in Negro children. T. M. Newcomb ve E. L. Hartley (Ed.), Readings in social psychology içinde (ss. 169-178). New York, NY: Holt: Rinehart \& Winston. doi:10.2307/2966491

Crocker, J. ve Major, B. (1989). Social stigma and self-esteem: The self-protective properties of stigma. Psychological Review, 96(4), 608-630. doi:10.1037/0033-295X.96.4.608

Çoymak, A. (2018). Kimmiş o ayrılıkçı: Türkiye'de uzun süredir devam eden Türk-Kürt çatışmasının çoklu sosyal kimlik dinamiklerini çözümlemek. Türk Psikoloji Yazılart, 21, 38-56.
De Cremer, D. (2001). Relations of self-esteem concerns, group identification, and self-stereotyping to in-group favoritism. Journal of Social Psychology, 141(3), 389-400.

Dökmen, Z. Y. (2015). Toplumsal cinsiyet: Sosyal psikolojik açıklamalar (6. bask1). İstanbul: Remzi Kitabevi.

Dumont, K. ve van Lill, B. (2009). Dominant and non-dominant groups' responses to social change: The economic transformation process in South Africa. South African Journal of Psychology, 39(4), 432-447. doi:10.1177/008124630903900405

Dunham, Y., Baron, A. S. ve Banaji, M. R. (2006). From American city to Japanese village: A cross-cultural investigation of implicit race attitudes. Child Development, 77(5), 1268-1281.

Ellemers, N. ve Rijswijk, W. Van. (1997). Identity needs versus social opportunities: The use of group-level and individual-level identity management strategies. Social Psychology Quarterly, 60(1), 52-65. doi: $10.2307 / 2787011$

Ellemers, N., van Knippenberg, A., De Vries, N. ve Wilke, H. (1988). Social identification and permeability of group boundaries. European Journal of Social Psychology, 18(6), 497-513. doi:10.1002/ ejsp. 2420180604

Ellemers, N., Wilke, H. ve van Knippenberg, A. (1993). Effects of legitimacy of low group or inidvidual status on individual and collective status enhancement strategies. Journal of Personality and Social Psychology, 64(5), 766-778.

Ergil, D. (2009). Kürt raporu: Güvenlik politikalarından kimlik siyasetine. İstanbul: Timaş Yayıncılık.

Erikson, E. H. (1956). The problem of ego identity. Journal of the American Psychoanalytic Association, 4(1), 56-121. doi:10.1177/000306515600400104

Fiedler, S., Hellmann, D. M., Dorrough, A. R. ve Glöckner, A. (2018). Cross-national in-group favoritism in prosocial behavior: Evidence from Latin and North America. Judgment and Decision Making, 13(1), 42-60.

Gaertner, S. L., Dovidio, J. F., Anastasio, P. A., Bachman, B. A. ve Rust, M. C. (1993). The common ingroup identity model: Recategorization and the reduction of intergroup bias. European Review of Social Psychology, 4(1), 1-26. doi:10.1080/14792779343000004

Göregenli, M. (2015). Şiddet ve işkencenin meşrulaştırılması sürecinin sosyal psikolojik arka planı. (17.05.2018 tarihinde https://www.hyd.org.tr/attachments/article/208/iskencenin-haritalanmasi-melek-goregenli.pdf adresinden alınmıştır.)

Greenwald, A. G. (1990). What cognitive representati- 
ons underlie social attitudes? Bulletin of the Psychonomic Society, 28(3), 254-260. doi:10.3758/ BF03334018

Greenwald, A. G., McGhee, D. E. ve Schwartz, J. L. K. (1998). Measuring individual differences in implicit cognition: The implicit association test. Journal of Personality and Social Psychology, 74(6), 1464-80. doi:10.1037/0022-3514.74.6.1464

Güler, M. (2013). Gruplar arası temas, kaygı ve yanllliğın sosyal mesafeye etkisi: Türk ve Kürt kökenli gruplar üzerine bir çalışma. Yayınlanmamış doktora tezi, Ankara Üniversitesi, Ankara.

Hasta, D. ve Karaçanta, H. (2017). Yetkecilik, sosyal baskınlık yönelimi ve siyasal görüş. Türk Psikoloji Yazılarl, 20(40), 23-34.

Henry, P. J., Sidanius, J., Levin, S. ve Pratto, F. (2005). Social dominance orientation, authoritarianism, and support for intergroup violence between the Middle East and America. Political Psychology, 26(4), 569-583. doi:10.1111/j.1467-9221.2005.00432.x

Hewstone, M., Rubin, M. ve Willis, H. (2002). Intergroup bias. Annual Review of Psychology, 53(1), 575-604. doi:10.1146/annurev.psych.53.100901.135109

Hogg, M. A. ve Abrams, D. (1998). Social identifications: A social psychology of intergroup relations and group processes. New York, NY: Routledge.

Hortaçsu, N. (2007). Ben, biz, hepimiz: Toplumsal kimlik ve gruplararası ilişkiler. Ankara: İmge Kitabevi.

Jost, J. T. (2001). Outgroup favoritism and the theory of system justification: A paradigm for investigating the effects of socioeconomic success on stereotype content. G. Moskowitz (Ed.), Cognitive social psychology: The Princeton Symposium on the legacy and future of social cognition içinde (ss. 89-102). Mahwah, NJ: Erlbaum Press.

Jost, J. T. ve Banaji, M. R. (1994). The role of stereotyping in system-justification and the production of false consciousness. British Journal of Social Psychology, 33, 1-27.

Jost, J. T., Banaji, M. R. ve Nosek, B. A. (2004). A decade of system justification theory: Accumulated evidence of conscious and unconscious bolstering of the status quo. Political Psychology, 25(6), 881-919.

Jost, J. T. ve Hunyady, O. (2002). The psychology of system justification and the palliative function of ideology. European Review of Social Psychology, 13(1), 111-153.

Jost, J. T., Kivetz, Y., Rubini, M., Guermandi, G. ve Mosso, C. (2005). System-justifying functions of complementary regional and ethnic stereotypes: Cross-national evidence. Social Justice Research,
18(3), 305-333. doi:10.1007/s11211-005-6827-z

Jost, J. T., Pelham, B. W. ve Carvallo, M. R. (2002). Non-conscious forms of system justification: Cognitive, affective, and behavioral preferences groups. Journal of Experimental Social Psychology, 38, 586-602.

Jost, J. T. ve Thompson, E. P. (2000). Group-based dominance and opposition to equality as independent predictors of self-esteem, ethnocentrism, and social policy attitudes among African Americans and European Americans. Journal of Experimental Social Psychology, 36(3), 209-232. doi:10.1006/ jesp.1999.1403

Karaçanta, H. (2002). Üniversite öğrencilerinin sosyal baskınlı yönelimi ve başka bazı değişkenler açısından karşılaştırılması. Yayınlanmamış doktora tezi, Ankara Üniversitesi, Ankara.

Kelly, C. (1990). Social identity and intergroup perceptions in minority-majority contexts. Human Relations, 43(6), 583-599. doi:0803973233

Kessler, T. ve Mummendey, A. (2002). Sequential or parallel processes? A longitudinal field study concerning determinants of identity-management strategies. Journal of Personality and Social Psychology, 82(1), 75-88. doi:10.1037/0022-3514.82.1.75

Korkmaz, L. (2017). Tutumlarımızın ne kadar farkındayız? Örtük tutumlar ve örtük ölçüm yöntemleri. Türk Psikoloji Yazıları, 20(40), 109-127.

Levin, S., Federico, C. M., Sidanius, J. ve Rabinowitz, J. L. (2002). Social dominance orientation and intergroup bias: The legitimation of favoritism for high-status groups. Personality and Social Psychology Bulletin, 28(2), 144-157.

Levin, S., Matthews, M., Guimond, S., Sidanius, J., Pratto, F., Kteily, N., ... Dover, T. (2012). Assimilation, multiculturalism, and colorblindness: Mediated and moderated relationships between social dominance orientation and prejudice. Journal of Experimental Social Psychology, 48(1), 207-212. doi:10.1016/j.jesp.2011.06.019

Levin, S., Sinclair, S., Sidanius, J. ve Van Laar, C. (2009). Ethnic and university identities across the college years: A common in-group identity perspective. Journal of Social Issues, 65(2), 287-306. doi:10.1111/j.1540-4560.2009.01601.x

Liebkind, K., Henning-Lindblom, A. ve Solheim, E. (2006). Ingroup favouritism and outgroup derogation among Swedish-speaking Finns. Nordic Psychology, 58(3), 262-278. doi:10.1027/19012276.58.3.262

Mana, A., Sagy, S., Srour, A. ve Mjally-Knani, S. (2015). On both sides of the fence: Perceptions of collective narratives and identity strategies among Pales- 
tinians in Israel and in the West Bank. Mind and Society, 14(1), 57-83. doi:10.1007/s11299-0140159-3

Martiny, S. E., Kessler, T. ve Vignoles, V. L. (2011). Shall I leave or shall we fight? Effects of threatened group-based self-esteem on identity management strategies. Group Processes \& Intergroup Relations, 15(1), 39-55. doi:10.1177/1368430211415439

Moghaddam, M. F., Taylor, D. M. ve Lalonde, R. N. (1987). Individualistic and collective integration strategies among Iranians in Canada. International Journal of Psychology, 22, 301-313.

Mummendey, A., Kessler, T., Klink, A. ve Mielke, R. (1999). Strategies to cope with negative social identity: Predictions by social identity theory and relative deprivation theory. Journal of Personality and Social Psychology, 76, 229-245. doi:10.1037/0022-3514.76.2.229

Mummendey, A., Klink, A., Mielke, R., Wenzel, M. ve Blanz, M. (1999). Socio-structural characteristics of intergroup relations and identity management strategies: Results from a field study in East Germany. European Journal of Social Psychology, 29, 259-285. doi:10.1002/ (Sici)1099-0992(199903/05)29:2/3<259::Aid-Ejsp927>3.0.Co;2-F

Newheiser, A. K., Dunham, Y., Merrill, A., Hoosain, L. ve Olson, K. R. (2014). Preference for high status predicts implicit outgroup bias among children from low-status groups. Developmental Psychology, 50(4), 1081-1090. doi:10.1037/a0035054

Niens, U. ve Cairns, E. (2002). Identity management strategies in Northern Ireland. Journal of Social Psychology, 142(3), 371-380. doi:10.1080/00224540209603905

Niens, U. ve Cairns, E. (2003). Explaining social change and identity management strategies. Theory and Psychology, 13(4), 489-509.

Osborne, D., Jost, J. T., Becker, J. C., Badaan, V., ve Sibley, C. G. (2019). Protesting to challenge or defend the system? A system justification perspective on collective action. European Journal of Social Psychology, 49(2), 244-269. doi.org/10.1002/ ejsp. 2522

Pratto, F., Sidanius, J. ve Levin, S. (2006). Social dominance theory and the dynamics of intergroup relations: Taking stock and looking forward. European Review of Social Psychology, 17(1), 271-320. doi:10.1080/10463280601055772

Pratto, F., Sidanius, J., Stallworth, L. M. ve Malle, B. F. (1994). Social dominance orientation: A personality variable predicting social and political attitudes. Journal of Personality and Social Psychology,
67(4), 741-763. doi:10.1037/0022-3514.67.4.741

Rabinowitz, J. L. (1999). Go with the flow or fight the power? The interactive effects of social dominance orientation and perceived injustice on support for the status quo. Political Psychology, 20(1), 1-24.

Roccas, S. (2003). The effects of status on identification with multiple groups. European Journal of Social Psychology, 33, 351-366.

Rubin, M., Badea, C. ve Jetten, J. (2014). Low status groups show in-group favoritism to compensate for their low status and compete for higher status. Group Processes \& Intergroup Relations, 17(5), 563-576. doi:10.1177/1368430213514122

Saleem, M. ve Ramasubramanian, S. (2017). Muslim Americans' responses to social identity threats: Effects of media representations and experiences of discrimination. Media Psychology, 22(3), 373-393. doi:10.1080/15213269.2017.1302345 UPDATE this

Scheepers, D., Spears, R., Doosje, B. ve Manstead, A. S. R. (2006). The social functions of ingroup bias: Creating, confirming, or changing social reality. European Review of Social Psychology, 17, 359396. doi:10.1080/10463280601088773

Schermelleh-Engel, K., Moosbrugger, H. ve Müller, H. (2003). Evaluating the fit of structural equation models: Tests of significance and descriptive goodness-of-fit measures. Methods of Psychological Research Online, 8(2), 23-74. doi: 10.1002/0470010940

Sidanius, J. ve Pratto, F. (1999). Social dominance: An intergroup theory of social hierarchy and oppression. New York, NY: Cambridge University Press.

Sidanius, J., Pratto, F., Van Laar, C. ve Levin, S. (2004). Social dominance theory: Its agenda and method. Political Psychology, 25(6), 845-880. doi:10.1111/ j.1467-9221.2004.00401.x

Tajfel, H. (1974). Social identity and intergroup behaviour. Social Science Information, 13(2), 65-93. doi: $10.1177 / 053901847401300204$

Tajfel, H. (1975). The exit of social mobility and the voice of social change: Notes on the social psychology of intergroup relation. Social Science Information, 14(2), 101-118.

Tajfel, H. ve Turner, J. C. (1979). An integrative theory of intergroup conflict. W. G. Austin ve S. Worche (Ed.), The social psychology of intergroup relations içinde (ss. 33-47). Monterey, CA: Brooks-Cole. doi:10.1016/S0065-2601(05)37005-5

Taylor, D. M. ve McKirnan, D. J. (1984). Theoretical contributions: A five-stage model of intergroup relations. British Journal of Social Psychology, 23(4), 291-300. 
Ufkes, E. G., Dovidio, J. F. ve Tel, G. (2015). Identity and collective action among European Kurds. British Journal of Social Psychology, 54, 176-186. doi:10.1111/bjso. 12084

Uluğ, Ö. M., Odağ, Ö., Cohrs, J. C. ve Holtz, P. (2017). Understanding the Kurdish conflict through the eyes of Kurds and Turks: New conflict reflections from lay people in Turkey. International Journal of Conflict Management, 28(4), 483-508. doi:10.1108/ijcma-05-2016-0035

van der Toorn, J. ve Jost, J. T. (2014). Twenty years of system justification theory: Introduction to the special issue on "Ideology and system justification processes." Group Processes \& Intergroup Relations, 17(4), 413-419. doi:10.1177/1368430214531509

Verkuyten, M. (1998). Perceived discrimination and self-esteem among ethnic minority adolescents. Journal of Social Psychology, 138(4), 479-493. doi:10.1080/00224549809600402

Verkuyten, M. ve Reijerse, A. (2008). Intergroup structure and identity management among ethnic minority and majority groups: The interactive effects of perceived stability, legitimacy, and permeability. European Journal of Social Psychology, 38, 106-127.

Wright, S. C. (2009). The next generation of collective action research. Journal of Social Issues, 65(4), 859-879. doi:10.1111/j.1540-4560.2009.01628.x

Yıldırım, Z. M., Turhan, F. ve Kuşdil, M. E. (2020). Social psychological factors behind ethnic discrimination in employee selection. Boğaziçi Journal Review of Social, Economic and Administrative Studies, 34(1), 1-23 doi: 10.21773/boun.34.1.1 